\title{
Revisão taxonômica de MachaERium Sect. Oblonga (BENTH.) Taub. (Leguminosae, Papilionoideae, Dalbergieae) ${ }^{1}$
}

Carlos Victor Mendonça Filho², Ana Maria Goulart de Azevedo Tozzi ${ }^{3}$

\& Eliana R. Forni Martins ${ }^{3}$

\begin{abstract}
RESUMO
(Revisão taxonômica de Machaerium sect. Oblonga (Benth.) Taub. (Leguminosae, Papilionoideae, Dalbergieae)) Na presente revisão taxonômica foram reconhecidas 12 espécies: M. floridum, M. goudoti, M. gracile, $M$. hatschbachii, M. myrianthum, $M$. nyctitans, $M$. obovatum, . ovalifolium, $M$. ruddianum, $M$. saraense, $M$. scleroxylon e M. tortipes. Não foram reconhecidos táxons infra-específicos para $M$. nyctitans que teve sua circunscrição modificada. Foi proposto um nome novo, M. ruddianum, para M. floridum var. parviflorum. Foram também reconhecidos novos sinônimos para M. myrianthum e M. nyctitans e designado um epitipo para esta última espécie. As espécies da seção apresentam uma distribuição disjunta, com algumas espécies ocorrendo principalmente na Região Sudeste do Brasil e outras em países da região Amazônica e da América Central.

Palavras-chave: Taxonomia, Leguminosae, Papilionoideae, Dalbergieae, Machaerium.
\end{abstract}

\section{Abstract}

(Taxonomic survey of Machaerium sect. Oblonga (Benth.) Taub. (Leguminosae, Papilionoideae, Dalbergieae)) Twelve species were recognized in the present revision: M. floridum, M. goudoti, M. gracile, M. hatschbachii, M. myrianthum, M. nyctitans, M. obovatum, M. ovalifolium, M. ruddianum, $M$. saraense, $M$. scleroxylon and M. tortipes. M. nyctitans had its circumscription modified and infraspecific taxa were not recognized for this species. A new name, $M$. ruddianum, was proposed to replace $M$. floridum var. parviflorum. New synonyms were recognized for M. myrianthum and $M$. nyctitans and an epitype was designated for this last species. The species of this section show disjunct distribution, with some species occuring mainly in Southeastern Brazil and others in countries from the Amazon basin and Central America.

Key words: Taxonomy, Leguminosae, Papilionoideae, Dalbergieae, Machaerium.

\section{INTRODUÇÃo}

O gênero Machaerium Pers. está subordinado à tribo Dalbergieae (Leguminosae, Papilionoideae). Constitui-se por cerca de 130 espécies com distribuição tipicamente neotropical, estendendo-se do sul do México à América do Sul, com apenas uma espécie ocorrendo na costa oeste da África (Rudd 1977). A maior diversidade ocorre no Brasil, onde são encontradas cerca de 120 espécies, variando desde árvores a até plantas escandentes (Hoehne 1941). As formas escandentes predominam na hiléia amazônica, enquanto as arbóreas, no centro-sul do Brasil (Ducke 1949).

Machaerium é um gênero que apresenta uma grande riqueza específica na maioria dos inventários florísticos, nos mais variados habitats e apresenta ampla distribuição geográfica (Ducke 1922, 1949; Barroso 1965; Bastos 1987; Lewis 1987; Lima et al. 1994; Mendonça 1996; Sartori \& Tozzi 1998). A despeito desta importância, é necessário ampliar-se o estudo sobre o gênero, devido à dificuldade de delimitação de muitas espécies.

As 56 espécies de Machaerium então conhecidas foram agrupadas em cinco séries por Bentham (1860), utilizando caracteres vegetativos, principalmente forma e venação dos folíolos e presença de estípulas espinescentes. Estas foram elevadas à categoria de seções por Taubert (1891): Machaerium sect. Penninervea, M. sect.

\footnotetext{
Artigo recebido em 07/2006. Aceito para publicação em 03/2007.

${ }^{1}$ Parte da tese de doutorado do primeiro autor realizada junto ao Programa de Pós-graduação em Biologia Vegetal, Unicamp. ${ }^{2}$ Universidade Federal dos Vales do Jequitinhonha e Mucuri. Rua da Glória, 187, Centro, 39100-000, Diamantina, MG, Brasil.cvictor@jknet.com.br ${ }^{3}$ Universidade Estadual de Campinas, Depto. Botânica, Instituto de Biologia, Cx.Postal 6109, 13083-970, Campinas, SP, Brasil.
} 
Lineata, M. sect. Oblonga, M. sect. Reticulata e M. sect. Acutifolia. Rudd (1987) indicou o autônimo Machaerium sect. Machaerium para substituir a secão Penninervea, na qual estava inserida a espécie tipo do gênero: $M$. ferrugineum (Willd.) Pers., atualmente sinônimo de $M$. quinata (Aubl.) Sandwith. A autora reconheceu quatro seções para o gênero, sugerindo a inclusão das espécies da seção Acutifolia em Machaerium sect. Reticulata, sem tratá-las formalmente como sinônimos.

Das seções do gênero, Machaerium sect. Oblonga é particularmente complexa, devido à grande variação morfológica observada especial-mente em $M$. nyctitans, que tem resultado na dificuldade de delimitação da espécie e levantado discussões sobre o reconhecimento de táxons infraespecíficos (Rudd 1973; Lima et al. 1994; Lima 1995; Sartori \& Tozzi 1998). Por outro lado, a observação de espécies correlatas a esse táxon, caracteriza a existência de um “complexo taxonômico" que necessita ser mais bem investi-gado. A atualização das descrições das espécies permitirá uma melhor delimitação dos táxons, bem como a verificação de caracteres unificadores para a caracterização desta seção, principalmente reprodutivos, como soldadura dos estames e características do embrião e da plântula, uma vez que os caracteres vegetativos muitas vezes não tem sido suficientes para separar seções afins.

Bentham (1860) tratou nove espécies em Machaerium sect. Oblonga: $M$. gardneri, M. goudoti, M. gracile, $M$. moritzianum, M. myrianthum, M. nyctitans, M. scleroxylon, M. polyphyllum (Poir.) e $M$. sordidum Benth. A composição da seção foi ampliada com a inclusão de $M$. multifoliolatum Ducke por Bastos (1987) e de $M$. cobanense Donn. Sm. e $M$. cirrhiferum Pittier, por Rudd (1977).

Com o intuito de ampliar o atual conhecimento taxonômico de Machaerium, considerando a escassez de revisões taxonômicas recentes (a última foi de Hoehne 1941), o presente trabalho teve como objetivos atualizar a nomenclatura, tipificação e circunscrição dos táxons de Machaerium sect. Oblonga; realizar descrições e ilustrações, apresentar chave para identificação das espécies e informações sobre sua distribuição geográfica, hábitat e épocas de floração e frutificação.

\section{Material e Métodos}

Foram analisadas cerca de 1500 exsicatas de 26 herbários nacionais e 16 herbários do exterior, cujas siglas designativas estão de acordo com Holmgren et al. (1990). Foram realizadas coletas adicionais e observações de campo, especialmente daquelas espécies que necessitaram de maiores estudos, nos estados da Bahia, Espírito Santo, Minas Gerais, Paraná, São Paulo e Rio de Janeiro. O material coletado foi depositado no herbário UEC e duplicatas foram enviadas aos herbários BHCB, CVRD, MBML e VIC.

A citação dos tipos foi realizada de acordo com o apresentado na obra princeps. A terminologia utilizada na caracterização morfológica foi baseada em Radford et. al. (1974) e Stearn (1983). As medidas das flores foram tomadas a partir da base do cálice. Os ápices dos lacínios do cálice foram descritos como lobados (obtusos, com ângulo maior que $\left.90^{\circ}\right)$, triangulares ou estreitamente triangulares (com ângulo menor que $90^{\circ}$ ). As medidas do vexilo, asas e das pétalas da carena incluíram a unha. A medida do comprimento do fruto incluiu o estipe. As partes florais e detalhes de outras estruturas foram ilustradas com o auxílio de estereomicroscópio Zeiss, com câmara clara acoplada. Amostras de flores foram fixadas em solução de formol, ácido acético e álcool (FAA 50\%) para ilustração de detalhes florais.

A classificação do hábitat das espécies está de acordo com Andrade-Lima (1966) para as espécies brasileiras e com Cabrera \& Willink (1973) para as espécies extra-brasileiras. 


\section{Resultados e Discussão}

Machaerium sect. Oblonga (Benth.) Taub. In: Engler \& Prantl., Naturl. Pflanzenfam. 3:337. 1891. (Lectótipo, aqui designado: Machaerium nyctitans (Vell.) Benth.).

Machaerium ser. Oblonga Benth., J. Linn. Soc. Bot., 4 Suppl.: 53. 1860.

Lianas, arbustos-escandentes, arvoretas a árvores, até $30 \mathrm{~m}$ alt. Estípulas espinescentes, retas ou recurvadas, $4-45 \mathrm{~mm}$ compr., às vezes decíduas. Folhas 7-65(150)-folioladas, folíolos oblongos, $0,5-5,6 \times$ $0,2-2 \mathrm{~cm}$, o terminal geralmente obovado, obtuso a retuso, base cuneada, venação broquidódroma. Racemos a panículas 2,5$40(-80) \times 0,7-20 \mathrm{~cm}$, axilares ou terminais, laxos ou congestos nos ápices, pauci a multifloros. Brácteas e bractéolas orbiculares, ovadas, obovadas, lanceoladas a triangulares, às vezes cimbiformes. Flores até $12 \mathrm{~mm}$ compr., sésseis a pediceladas; estames monadelfos a diadelfos (estame vexilar livre), às vezes na mesma espécie; ovário uniovulado; disco nectarífero cupulado. Sâmaras até $8 \mathrm{~cm}$ compr., cultriformes; asas concolores ou discolores na base, de coloração distinta do núcleo seminífero. Plúmula pluripartida, germinação faneroepígea, eófilos plurifoliolados. $2 \mathrm{n}=20$, 40 Américas Central e do Sul.

Das nove espécies tratadas por Bentham (1860) foram mantidas na seção Oblonga cinco espécies: $M$. goudoti, M. gracile, $M$. myrianthum, M. nyctitans e M. scleroxylon.
M. sordidum Benth. trata-se de um sinônimo de Dalbergia villosa Benth. (Carvalho 1997) e $M$. gardneri foi considerado uma variedade de M. nyctitans (Rudd 1973). A análise de material de diferentes herbários indicou que M. moritzianum Benth. e M. polyphyllum Benth. apresentam características de folhas e flores afins às das espécies de Machaerium sect. Lineata e devem ser transferidas para esta seção. Bentham (1860) reconheceu uma maior proximidade da primeira espécie com $M$. angustifolium (atualmente M. hirtum), subordinada à seção Lineata. Quanto a $M$. polyphyllum, o autor baseou-se na descrição de De Candolle (1825) para Nissolia polyphylla e não teve oportunidade de examinar as flores desta espécie e comparála com as demais descritas por ele para Machaerium sect. Oblonga. Ducke (1922) observou uma semelhança de M. polyphyllum com $M$. angustifolium corroborando a sua transferência. Outras duas espécies, $M$. cobanense e $M$. cirrhiferum, também tiveram material de herbário examinado e por apresentarem características florais semelhantes às das espécies de Machaerium sect. Lineata também devem ser tratadas nesta seção. M. multifoliolatum foi aqui considerada sinônimo de M. myrianthum.

Neste trabalho foram reconhecidas 12 espécies pertencentes a Machaerium sect. Oblonga dentre elas um nome novo: $M$. ruddianum C. V. Mendonça F. \& A. M. G. Azevedo.

\section{Chave para a identificação das espécies de Machaerium sect. Oblonga}

1. Folíolo terminal maior que $0,7 \mathrm{~cm}$ larg.

2. Raque da folha $15-19 \mathrm{~cm}$ compr. 12. M. tortipes

2. Raque da folha menor que $12 \mathrm{~cm}$ compr.

3. Raque foliar e superfície abaxial dos folíolos glabras; pecíolo $0,5 \mathrm{~mm}$ diâm.

4. Ramos inermes; folíolos membranáceos; peciólulo 1-2 mm compr.; frutos 5,8$6 \mathrm{~cm}$ compr.; núcleo seminífero glabro. Sara, Bolívia 10. M. saraense

4. Ramos aculeados; folíolos cartáceos; peciólulo $1 \mathrm{~mm}$ compr.; frutos até $5 \mathrm{~cm}$ compr.; núcleo seminífero fulvo-seríceo. Cabo Frio-RJ, Brasil 7. M. obovatum

3. Raque foliar e superfície abaxial dos folíolos pilosas; pecíolo $1 \mathrm{~mm}$ diâm. 
5. Inflorescência laxa; flores com bractéolas menores do que o cálice.

6. Cálice e bractéolas estriados externamente; lacínios do cálice obtusos; vexilo atenuado na base; núcleo seminífero enegrecido, asa discolor na base

11. M. scleroxylon

6. Cálice e bractéolas lisos; lacínios do cálice triangulares; vexilo auriculado na base; núcleo seminífero castanho, asa concolor

9. M. ruddianum

5. Inflorescência congesta no ápice; flores com bractéolas do tamanho do cálice.

7. Tricomas de base dilatada presentes nas margens dos lacínios e bractéolas; estipe maior que $1,5 \mathrm{~mm}$ compr., estilete até $2,5 \mathrm{~mm}$ compr. 6. M. nyctitans

7. Tricomas de base dilatada ausentes; estipe $1 \mathrm{~mm}$ compr., estilete maior que $3 \mathrm{~mm}$ compr.

8. M. ovalifolium

1. Folíolo terminal até $0,7 \mathrm{~cm}$ larg.

8. Peciólulo até $0,5 \mathrm{~mm}$ compr. (folíolos subsésseis).

9. Superfície adaxial dos folíolos nítida, brilhante, nervuras secundárias imersas no mesofilo

5. M. myrianthum

9. Superfície adaxial dos folíolos opaca, nervuras secundárias salientes.

10. Lianas; pedicelos 1,5-2 mm compr.; bractéolas orbiculares; ovário fulvo-viloso; frutos falcados; Sudeste do Brasil...

10. Subarbustos a árvores; pedicelos $1 \mathrm{~mm}$ compr.; bractéolas lanceoladas; ovário ferrugíneo-seríceo; frutos ovados; Panamá

3. M. goudoti

8. Peciólulo maiores que $0,5 \mathrm{~mm}$ compr.

11. Bractéolas do tamanho do cálice; bainha de estames glabra; estigma conspícuo ......

4. M. hatschbachii

11. Bractéolas menores que o cálice; bainha de estames puberulenta nas margens; estigma inconspícuo

1. M. floridum

1. Machaerium floridum (Mart. ex Benth.) Ducke, Arch. Jard. Bot. Rio de Janeiro 5: 135. 1930.

Fig. 1

Drepanocarpus floridus Mart. ex Benth., Comm. Legum. Gen.: 32. 1837; Ann. Mus. Vind. 2: 96. 1838. Typus: BRASIL. BAHIA: In sylvis provinciae Bahia, legit et communic. Pr. Vidensis, 1829, Herbarium Martii (Lectótipo, aqui designado BR!; Isolectótipo BR!).

Árvore $4-8 \mathrm{~m}$ alt. Tronco $12-15 \mathrm{~cm}$ diâm., acúleos lineares com 8-10×2 mm na base, casca lisa, levemente fissurada, castanho-clara a acinzentada, lenticelada; cerne creme, exsudato resinoso. Ramos $2-$ $5 \mathrm{~mm}$ diâm., sulcados longitudinalmente, esbranquiçados, acinzentados a enegrecidos, lenticelados, glabros. Estípulas 5-7×1-2 mm, triangulares, retas, espinescentes. Folhas $3-$
$8 \times 1-3 \mathrm{~cm}, 17-25(-37)$-folioladas; pecíolo 0,4-1 cm compr., 0,5-1 mm diâm., cilíndrico, hialino-puberulento a ferrugíneo-viloso, às vezes glabrescente; raque $2-7,5 \mathrm{~cm}$ compr., 0,5-1 mm diâm., cilíndrico, indumento como no pecíolo; peciólulo $0,5-1 \mathrm{~mm}$ compr. Folíolos alternos a subopostos, 0,4-2 × 0,3$0,7 \mathrm{~cm}$, ápice obtuso, levemente retuso, mucronulado, base arredondada, obtusa, cuneada a oblíqua, cartáceos, discolores, margens inteiras, espessadas, revolutas, superfície adaxial esparsamente hialinoserícea a glabrescente, superfície abaxial flava a hialino-serícea a vilosa na base, glabrescente, venação broquidódroma. Panículas 2,5-12,5 × (1-)1,5-7,5 cm, até 3 vezes o comprimento das folhas, terminais, às vezes axilares, laxas, multifloras; pedúnculo 0-1,7 cm compr., 0,5-1,5 mm diâm.; raque 

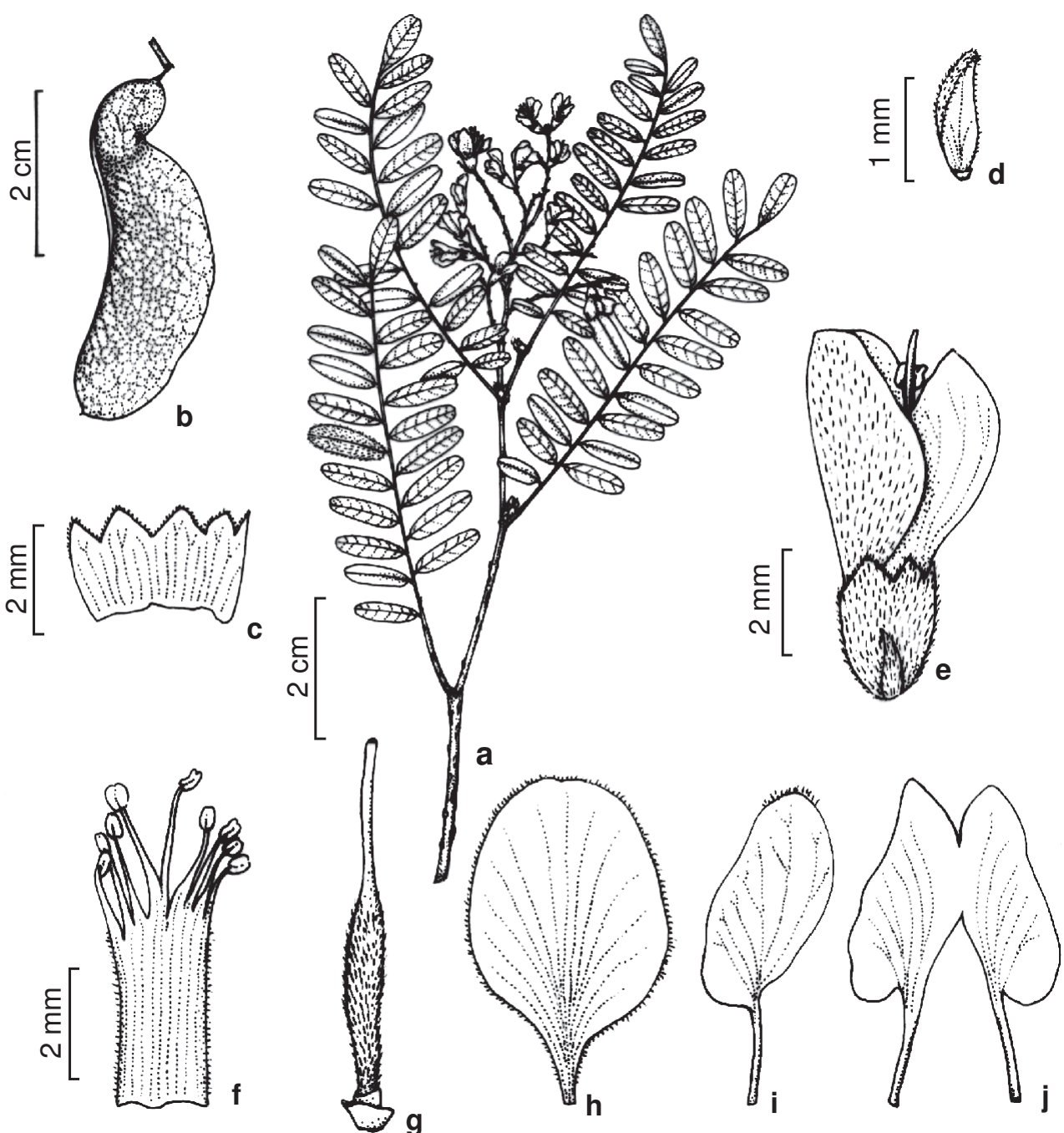

Figura 1 - Machaerium floridum (Mart. ex Benth.) Ducke - a. ramo e inflorescência; b. fruto; c. cálice; d. bractéola; e. flor em antese; f. androceu; g. gineceu; h. vexilo; i. asa; j. pétalas da carena. (a Mori 10060; b Braz. 76; c-1 Santos 3205)

1,4-11,5 cm compr., canescente-serícea a ferrugíneo-tomentosa; eixos laterais $0,5-3,6 \mathrm{~cm}$ compr., indumento como na raque. Brácteas $1-3 \times 0,5-2 \mathrm{~mm}$, triangulares a ovadas, côncavas, canescente-tomentosas a ferrugíneo-seríceas, membranáceas. Flores sésseis a subsésseis, 5-9 mm compr.; bractéolas 1,5-2,5 ×0,5$1 \mathrm{~mm}$, triangulares, cimbiformes, carnosas, lisas, hialino-lanosas a ferrugíneo-tomentosas; cálice 2,5-3 × 1-2,5 mm, 1,6-2 mm diâm., superfície lisa, hialina-serícea a ferrugíneotomentosa, lacínios triangulares, os carenais $0,5 \times 0,5 \mathrm{~mm}$, os vexilares $0,5 \times 0,8 \mathrm{~mm}$; corola
3-3,5 vezes o compr. do cálice, pétalas brancas, com nervuras avermelhadas, dicotômicas, às vezes inconspícuas, como também as superfícies internas das bractéolas e do cálice; vexilo 6-7 ×4 mm, ovado, superfície externa hialino-serícea a ferrugíneo-tomentosa, superfície interna flavo-tomentosa na margem a glabra, carnoso, ápice obtuso, mucronulado, base atenuada, unha 1,5 mm compr.; asas 6-6,5×1,5-2 mm, elípticas, esparsamente fulvo-seríceas a puberulentas no dorso, membranáceas, ápice obtuso, base levemente auriculada, unha 
1,5-2,5 mm compr.; pétalas da carena 6-7×2 $\mathrm{mm}$, elípticas, glabras, membranáceas, ápice agudo a obtuso, base auriculada, oblíqua, unha 2-2,5 mm compr.; estames 10 , monadelfos, às vezes diadelfos, soldados até $3-4$ mm compr.; filetes 4-6 mm compr., hialino-vilosos a ferrugíneo-tomentosos nas laterais da bainha, a hialino-vilosos nos estames vexilares, ao longo do filete; anteras $0,5 \times 0,5 \mathrm{~mm}$, oblongas; disco nectarífero $0,5 \times 0,5 \mathrm{~mm}$, cupulado; ovário estipitado, 2-2,5 $\times 0,5-0,8 \mathrm{~mm}$, hialino a ferrugíneo-seríceo, uniovulado; estipe 1-1,5 $\mathrm{mm}$, hialino a ferrugíneo-puberulento a seríceo; estilete 2,5-3 mm compr., glabro. Fruto 3-4,6 cm compr.; estipe 0,2-0,4 cm compr., canescente, flavo a ferrugíneo-tomentoso; núcleo seminífero $1-1,2 \times 0,6-0,7 \mathrm{~cm}, 2-2,5$ $\mathrm{mm}$ diâm., verde quando imaturo, castanho escuro quando maturo, ferrugíneo-puberulento a seríceo, superfície reticulada, fibroso; asa 2,4-3 × 0,8-1,3 cm, lanceolada, apresentando ângulo menor que $90^{\circ}$ em relação ao núcleo seminífero, vinosa quando imatura, quando matura concolor, castanho-clara, esparsamente flavo-serícea a hialino-puberulenta, lisa, reticulada, cartácea, ápice agudo a obtuso, mucronulado, às vezes apiculado, margem plana a levemente encurvada. Semente $8 \times 4$ $\mathrm{mm}$; testa castanho-escura, ruminada da rafe a 1/4 da margem, o restante corrugada; embrião com primórdios foliares pluripinulados.

Material examinado: BRASIL. BAHIA?: Campo Geral, 1829, C. P. von Martius s.n. (BM, K-Hb. Hook.; Foto BM: UEC!); BAHIA: Caetité, rod. p/ Bom Jesus da Lapa, 17.VI.1986, fr., G. Hatschbach \& F. J. Zelma 50458 (CEPEC, K, MBM, MO, UC, US); Igaporã, 13.V.1978, fl., J. S. Silva 500 (F, SP, NY); Maracás, 13 a $22 \mathrm{~km}$ ao sul, antiga rod. Jequié, 27.IV.1978, fl., S. A. Mori et al. 10060 (CEPEC, K); MINAS GERAIS: Aguas Vermelhas, próximo à comunidade Maristela, 9.XI.2000, est., C. V. Mendonça \& R. Belinello 628 (BHCB, UEC); Itaobim, 28.IV.1983, fl., C. T. Rizzini \& A.-Mattos-Filho 1567 (K, RB).

Fenologia: floração de março a maio e frutificação maio a agosto.

Hábitat e distribuição geográfica: mata seca, mata de cipó, caatinga arbórea. Solo arenoso/argiloso. Brasil: Bahia e Minas Gerais. Nome Popular: "bastião-de-arruda" (Bahia).
Neste trabalho está sendo feita a correção sobre o tipo da espécie. Em diversas exsicatas, assinaladas com a informação "Campo Geral, Brasil, Martius" que estão listadas no material examinado, constavam etiquetas assinaladas pela Dra. Velva E. Rudd, indicando tratar-se aparentemente de um isótipo de Drepanocarpus floridus Mart. ex Benth. var. floridus. Numa dessas exsicatas (K-Hb. Hook.) há uma interrogação feita por Martius sobre a possibilidade de tratar-se de uma Dalbergia. Essas informações não correspondem ao que foi apresentado no protólogo da espécie. Entretanto, há duas exsicatas no herbário de Bruxelas nas quais constam etiquetas com as mesmas informações do protólogo e, portanto, certamente correspondem à coleção sintípica.

A espécie apresenta afinidade com $M$. nyctitans e $M$. scleroxylon como indicado por Benthan (1862) e Hoehne (1941) e também com $M$. ruddianum. Distingue-se de $M$. nyctitans pelo menor tamanho dos folíolos, pelas estípulas menores, pelas inflorescências mais curtas, menos ramificadas, pelas brácteas e bractéolas e pelas flores e frutos menores, pela asa do fruto mais estreita. Diferencia-se de $M$. scleroxylon pelo menor porte e tronco liso, pelas inflorescências mais longas, bractéolas maiores, lanceoladas, pelo cálice liso e estipe normalmente mais curto e pela coloração homogênea da asa do fruto. Diferencia-se de $M$. ruddianum pelo estilete mais longo, vexilo ovado e androceu pubescente na margem da bainha e pelo disco nectarífero inconspícuo e assemelha-se pelas características do tronco e das folhas.

2. Machaerium gracile Benth., Comm. Legum. Gen. 34. 1837; ann. Mus. Vind. 2: 98 (1838). In: Martius \& Eichler (eds.). Fl. bras. 15(1): 240. 1862. Typus: BRASIL: Schott s.n. (Holótipo K-Hb. Benth.!; Foto K: AMES!, NY!, S!, UEC!).

Fig. 2

Liana. Tronco com seção cilíndrica, acúleos 4,5-10×1-3 mm, lineares a triangulares, casca lisa, acinzentada, sulcada, lenticelas circulares, cerne creme, exsudato avermelhado. Ramos 4 mm diâm., rugosos, acinzentados a 


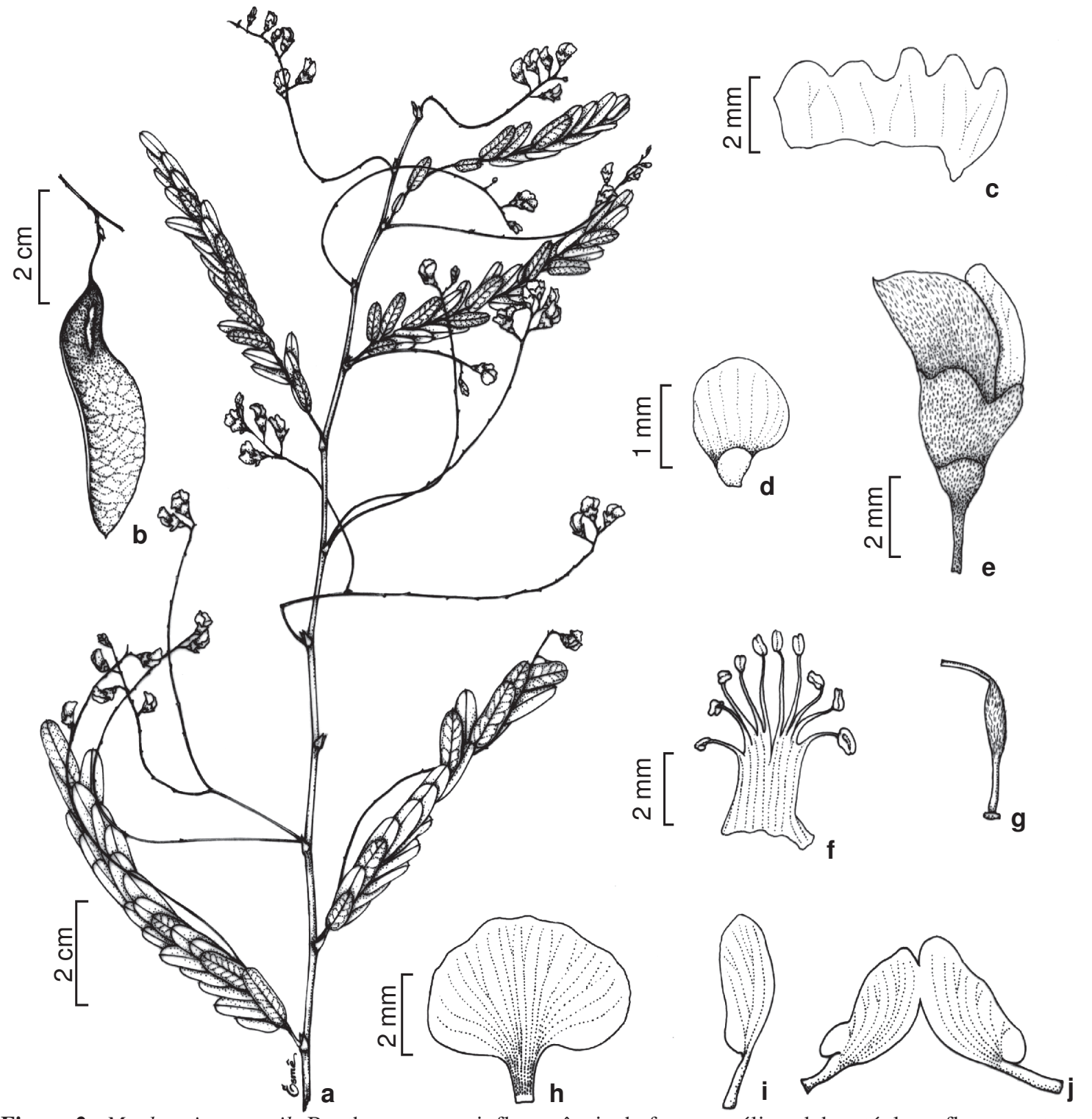

Figura 2 - Machaerium gracile Benth.- a. ramo e inflorescência; b. fruto; c. cálice; d. bractéola; e. flor em antese; f. androceu; g. gineceu; h. vexilo; i. asa; j. pétalas da carena. (a Pereira 7251; b Lima 3747; c-1 Sucre 6313)

enegrecidos, lenticelados, espinescentes, quando novos castanho-claros, glabros. Estípulas 2-3,7 $\times 1 \mathrm{~mm}$, triangulares, retas, espinescentes, estriadas, persistentes, às vezes decíduas. Folhas 4,5-15 × 1-2,5 cm, 15-50folioladas; pecíolo $0,4-0,8 \mathrm{~cm}$ compr., $0,6 \mathrm{~mm}$ diâm., ferrugíneo-seríceo; raque 4,7-6 cm compr., 0,4 mm diâm., indumento como no pecíolo; peciólulo $0,5 \mathrm{~mm}$ diâm. Folíolos alternos a subopostos, 1-2,2 ×0,3-0,7 cm, ápice obtuso, mucronulado, base obtusa, cuneada a oblíqua, cartáceos, levemente discolores, margens planas, espessadas, superfície adaxial glabra, superfície abaxial esparsamente ferrugíneoserícea, principalmente na nervura central, glabrescente, venação broquidódroma. Inflorescência racemosa a paniculada, 2,5-7 $\times$ 0,8-3 cm, do tamanho das folhas, axilar ou terminal, pêndula, laxa; pedúnculo (0-)1,3-2,3 cm compr., $0,5 \mathrm{~mm}$ diâm.; raque (0-)1-3,6 cm compr., ferrugíneo-puberulenta; eixos laterais 2,5$5,3 \mathrm{~cm}$ compr., indumento como na raque. Brácteas 1,3-3,3×0,1-0,6 mm, triangulares a filiformes, estriadas, ferrugíneo-seríceas, 
membranáceas, às vezes decíduas. Flores pediceladas, 5-6 mm compr:; pedicelo 1,5-2 $\mathrm{mm}$ compr., ferrugíneo-puberulento, glabrescente; bractéolas $1,2 \times 1 \mathrm{~mm}$, orbiculares, côncavas, carnosas, estriadas, ferrugíneo-puberulentas; cálice $2-3,5 \times 3 \mathrm{~mm}, 2 \mathrm{~mm}$ diâm., estriado longitudinalmente, ferrugíneo-puberulento, lacínios obtusos, os carenais $1-1,2 \times 1 \mathrm{~mm}$, os vexilares $1 \times 1-2 \mathrm{~mm}$; corola 2,5 vezes o compr. do cálice, pétalas alvo esverdeadas com nervuras violáceas, dicotômicas, como também as superfícies internas de bractéolas e cálice; vexilo 5-6×4-5 mm, oblado, superfície externa ferrugíneo-serícea, superfície interna glabra, carnoso, ápice plano, base auriculada, unha $1 \mathrm{~mm}$ compr.; asas 4,5-5,5 × 1,5 mm, oblongas, glabras no dorso, membranáceas, ápice obtuso, base levemente auriculada, unha 1,5 mm compr.; pétalas da carena 4,5$5,5 \times 2 \mathrm{~mm}$, elípticas, glabras no dorso, membranáceas, ápice obtuso, base auriculada, unha $2 \mathrm{~mm}$ compr.; estames 10 , monadelfos, soldados de 2 a 3,5 mm compr.; filetes 3,5-5 mm compr., glabros; anteras $0,5 \times 0,5 \mathrm{~mm}$, oblongas; disco nectarífero $0,2 \times 0,2 \mathrm{~mm}$, cupulado, inconspícuo; ovário estipitado, $1,5 \times 0,5 \mathrm{~mm}$, ferrugíneo-seríceo, uniovulado; estipe $1,5 \mathrm{~mm}$ compr., ferrugíneo-seríceo; estilete 1,5 mm compr., glabro; estigma levemente capitado. Frutos $3-$ 7,2 cm compr.; estipe $0,8-1,2 \mathrm{~cm}$ compr., esparsamente ferrugíneo-seríceo, glabrescente; núcleo seminífero 1,5-1,7×0,8-1cm, 3 mm diâm., castanho-escuro, glabro, superfície verrucosa, reticulada, fibroso; asa 2,5-4,5 × 1,2-1,5 cm, falcada, apresentando ângulo igual ou maior que $90^{\circ}$ em relação ao núcleo seminífero, homogênea, glabra, lisa, reticulada, cartácea, ápice obtuso a agudo, apiculado, margem plana. Semente reniforme, plano-comprimida. Material examinado: BRASIL. ESPÍRITO SANTO: Santa Teresa, Escola Agrotécnica Federal, 11.XII.1985, fl., W. Boone 971 (CEPEC), idem., 18.IX.2000, est., C. V. Mendonça \& L. Kollmann 574 (MBML, UEC); MINAS GERAIS: Carangola, Pedra do elefante, 13.XII.1988, fl., L. S. Leoni 582 (CEPEC, K); Coronel Pacheco, 10.II.1942, fl., E. P. Heringer 925 (US, VIC); RIO DE JANEIRO: Nova Friburgo, Macaé de Cima, Sítio São João, 6.VI.1989, fr., H. C. Lima et al. 3582 (BHCB, CEPEC, RB, SP).
Fenologia: floração de setembro a fevereiro e frutificação de março a agosto.

Hábitat e distribuição geográfica: floresta mesófila, floresta costeira, 680-1200 m.s.m. Brasil: Espírito Santo, Minas Gerais e Rio de Janeiro.

Foi observada foto do herbário $\mathrm{F}$ de uma exsicata de $M$. gracile com coleta de Schott 4302, proveniente do herbário de Viena. Abaixo da foto está grafada a indicação de holótipo da espécie, possivelmente pela Dra. V.E. Rudd. Entretanto, no herbário de K (Hb. Benth.), foi observada uma exsicata de material coletado por Schott, sem numeração, assim como referido no protólogo da espécie, e com manuscrito de Bentham na etiqueta, sendo reconhecido como o holótipo da espécie.

O porte de $M$. gracile lembra o de $M$. uncinatum (pertencente à seção Lineata) da qual diferencia-se pelos folíolos com venação broquidódroma (craspedódroma nesta última). As informações sobre as sementes foram compiladas de Lima et al. (1994). Estes autores citaram que $M$. gracile é uma espécie rara, exclusiva da porção sudeste da floresta pluvial atlântica que ocorre no Rio de Janeiro e Minas Gerais, sendo esta, portanto, a primeira citação para o Espírito Santo.

3. Machaerium goudoti Benth., J. Linn. Soc., Bot. 4 Suppl.: 59. 1860. Typus: Nova Granada: em Ratata ou Oratata (nome não legível), (Colômbia, Magdalena Valley), 1844, fl. e fr., M.J. Goudot s.n. (Síntipos G-DC-2, BM!, K!, UEC-foto K!).

Fig. 3

M. whitfordii J.F Macbr., Contrib. Gray Herb., n.s. 56: 53. 1918. Typus: COLÔMBIA, IUAGUAQUI: Boyacá, $180 \mathrm{~m}$ alt., 14.VI.1917, fr.; H.N. Whitford \& J. Pinzon 12 (Holótipo GH; Isótipos A, K!, UEC fotoFI!; US foto!).

Subarbustos a árvores até $20 \mathrm{~m}$ alt. Tronco 10-20 cm diâm., inerme, casca escamosa, fissurada, acinzentada; cerne enegrecido, exsudato avermelhado. Ramos 3-5 mm diâm., lisos, sulcados, acinzentados, glabros, lenticelados, espinescentes, quando novos esparsamente fulvo-estrigosos. Estípulas $0,6-0,8(-1) \times 0,1-$ 


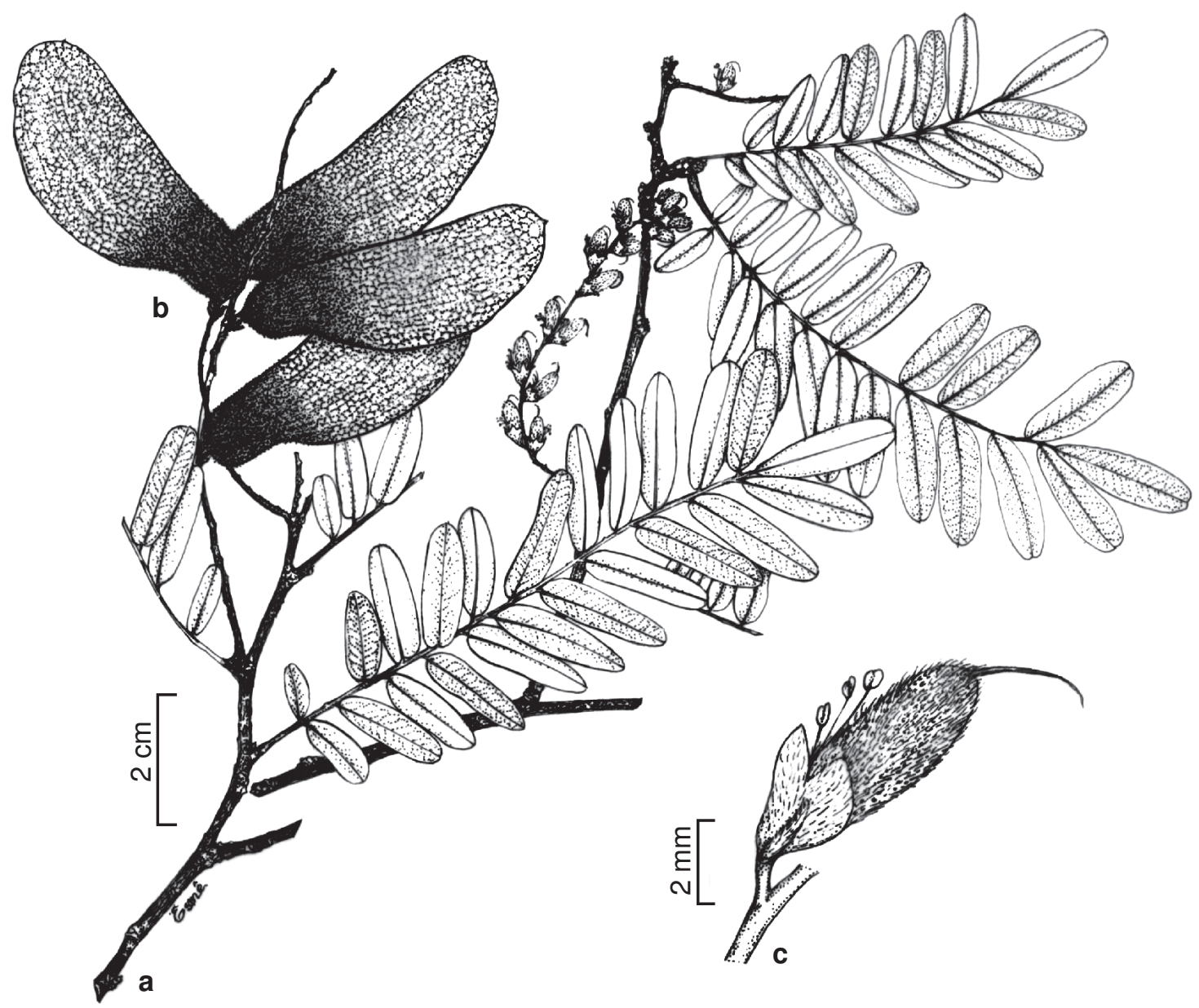

Figura 3 - Machaerium goudoti Benth.- a. ramo e inflorescência; b. fruto; c. ovário. (a-c Goudot s.n.)

$0,2 \mathrm{~cm}$, triangulares, lisas a estriadas, retas, espinescentes, às vezes decíduas. Folhas 1114,5 ×3-4 cm, 21-39-folioladas; pecíolo 0,758,7 cm compr., 1 mm diâm., fulvo-hirsuto; raque 8-10 cm compr., 1 mm diâm., indumento como no pecíolo; peciólulo $0,5 \mathrm{~mm}$ compr. Folíolos alternos, $1,2-2,4 \times 0,4-0,7 \mathrm{~cm}$, ápice retuso, base cuneada a oblíqua, cartáceos, discolores, margens levemente revolutas, espessadas, superfície adaxial glabrescente, superfície abaxial hialino-serícea, nervura principal avermelhada, venação broquidódroma. Racemos, $3,8-7,5 \times 1-1,5 \mathrm{~cm}, 1 / 2$ do compr. das folhas, axilar; pedúnculo $0,7-1 \mathrm{~cm}$ compr., $0,7 \mathrm{~mm}$ diâm., fulvo-tomentoso; raque 3,2-4 cm compr., indumento como no pedúnculo. Flores pediceladas, $8 \mathrm{~mm}$ compr., pedicelo $1 \mathrm{~mm}$ compr., fulvo-tomentoso; bractéolas 1,2-2 $\times 0,5 \mathrm{~mm}$, lanceoladas, estriadas, carnosas, glabras; cálice 2,5-4×2 mm, 2 mm diâm., superfície lisa, fulvoserícea, carnoso, lacínios carenais triangulares, 1-1,3×0,5 mm, lacínios vexilares lobados, $1 \times$ $1 \mathrm{~mm}$; corola 2-2,5 vezes o compr. do cálice; pétalas da carena $8 \mathrm{~mm}$ compr., conatas no dorso; estames 10, diadelfos; ovário $2,5 \times 2 \mathrm{~mm}$, fulvo-viloso; estipe e estilete $2 \mathrm{~mm}$ compr.; estilete glabro, encurvado; estigma capitado. Fruto 5-7 cm compr.; estipe 5-6 mm compr., fulvo-viloso; núcleo seminífero $1,5-6 \times 1 \mathrm{~cm}$, castanho-escuro, fulvo-tomentoso, superfície lisa, nervuras longitudinais prolongadas em direção ao ápice, fibroso; asa 3,5-4×1,7-2 cm, ovada, ângulo menor que $90^{\circ}$ em relação ao núcleo seminífero, homogênea, pardacenta, glabra, reticulada, cartácea, ápice obtuso, margem plana. Sementes não observadas. 
Material examinado: COLÔMBIA. Rio Tucurinca, 16.VIII.1936, est., A. Dugand 1015 (F); CUNDINAMARCA: 4.V.1944, fr., E. P. Killip et al. 38136 (F); PANAMA. CHIRIQUI: IV.1858, est., $M$. Wagner 319 (M).

Fenologia: floração não conhecida e frutificação de maio a junho.

Hábitat e distribuição geográfica: em áreas montanhosas. Colômbia e Panamá.

Nome popular: "negrillo"

No protólogo da espécie Bentham (1860) citou que foram examinadas duas exsicatas do herbário G-DC, que não foram aqui analisadas. Como os materiais analisados por Bentham não estavam, segundo o autor, em boas condições, nem tão pouco os demais materiais observados no MBM e K, não foi designado um lectótipo.

Essa espécie tem sido pouco coletada e por isto foi descrita através da análise da coleção típica, do auxílio da diagnose e de outras coleções. Bentham (1860) indicou que as características do ovário distinguem essa espécie das demais do gênero.

4. Machaerium hatschbachii Rudd, Phytologia 26(2): 100. 1973. Typus: BRASIL. PARANÁ: Campina Grande do Sul, Sítio do Belizário, 23.XI.1966, fl., G. Hatschbach 15254 (Holótipo US!; Isótipos C!, L!, MBM!, P, SI, UC!, UPCB!).

Fig. 4

Árvore 7-20 m alt. Tronco reto, $25-40 \mathrm{~cm}$ diâm., aculeados nos rebrotos, acúleos 8-12(-18) $\times 1-2 \mathrm{~mm}$ na base, triangulares, casca escamosa, acinzentada, com lenticelas horizontais, cerne creme, entrecasca avermelhada, exsudato ausente. Ramos 2-4 mm diâm., sulcados longitudinalmente, acinzentados a enegrecidos, glabros, lenticelados, espinescentes, às vezes inermes, quando novos glabros a esparsamente hialino a ferrugíneo-puberulentos, gemas axilares ovadas a lanceoladas. Estípulas (2-)6-8(-12) $\times 1-2 \mathrm{~mm}$, lineares a triangulares, retas, espinescentes, às vezes decíduas. Folhas (3-) 5,5-9(-13) ×1,5-2,5 cm, 15-25(-31)-folioladas; pecíolo 0,4-0,6(-1) cm compr., 0,4-0,5 mm diâm., cilíndrico, flavo-seríceo a ferrugíneo-estrigoso a tomentoso; raque $(2,5-) 4,5-8(-10,5) \mathrm{cm}$ compr., 0,5-0,7 mm diâm., cilíndrica, indumento como no pecíolo; peciólulo $0,5-1 \mathrm{~mm}$ compr. Folíolos alternos a subopostos, $(0,8-) 1,5-2,5 \times$ $0,3-0,7 \mathrm{~cm}$, ápice obtuso, retuso, mucronulado, base obtusa, cuneada a oblíqua, membranáceos a cartáceos, levemente discolores, margens inteiras, espessadas, revolutas, às vezes ciliadas, superfície adaxial esparsamente hialino a ferrugíneo-serícea, a glabra, superfície abaxial esparso a densamente hialino a flavo-serícea, venação broquidódroma. Racemos a panículas (1-)2-4 × 0,7-1,5(-4) cm, até 0,5 do compr. das folhas, axilares, laxas, palcifloras, às vezes com folhas entremeadas; pedúnculo (0-)0,30,7 cm compr., $0,5-1 \mathrm{~mm}$ diâm.; raque $0,5-2 \mathrm{~cm}$ compr.; ferrugíneo-serícea a tomentosa; eixos laterais 1,5-2 cm compr., indumento como na raque. Brácteas $2-7 \times 1-4 \mathrm{~mm}$, triangulares a ovadas, ferrugíneo-tomentosas, glabrescentes, endurecidas. Flores sésseis a subsésseis, $5-7 \mathrm{~mm}$ compr., pedicelo $0,2-0,5 \mathrm{~mm}$, ferrugíneo-seríceo a tomentoso; bractéolas 2-3,5 $\times(0,5-) 1-1,5 \mathrm{~mm}$, lanceoladas, cimbiformes, lisas, densamente ferrugíneo-seríceas a tomentosas; cálice 3-3,5 $\times$ 2,5-3 mm, 2,4-3 mm diâm., superfície lisa, ferrugíneo-serícea a tomentosa, lacínios carenais $(0,5-) 1-1,5 \times 0,5 \mathrm{~mm}$, estreitamente triangulares, lacínios vexilares triangulares $(0,5-) 1-1,5 \times 1,6-$ $2 \mathrm{~mm}$; corola $2-2,5$ vezes o compr. do cálice, pétalas vinosas, com nervuras avermelhadas, dicotômicas, como também as superfícies internas das bractéolas e do cálice; vexilo 5-6 $\times 5-6 \mathrm{~mm}$, oblado, superfície externa ferrugíneoserícea, superfície interna ferrugíneo-tomentosa na margem, ápice retuso, base levemente auriculada, unha 1-2 mm compr.; asas 5-5,5× 1,5-2 mm, elípticas, glabras a esparsamente hialino a ferrugíneo-seríceas no dorso, membranáceas, ápice obtuso, base auriculada, unha 1,5-2 mm compr.; pétalas da carena 4-5 $\times 2 \mathrm{~mm}$, falcado-elípticas, glabras a esparsamente hialino-seríceas no dorso, membranáceas, ápice obtuso, base auriculada, unha 1,5-2 mm compr.; estames 10, monadelfos, soldados até $2-3 \mathrm{~mm}$ compr.; filetes 3-4,5 mm compr., glabros; anteras $0,25-0,5 \times 0,25 \mathrm{~mm}$, oblongas; disco nectarífero 0,5-1 ×0,5-1 mm, cupulado; ovário estipitado, 


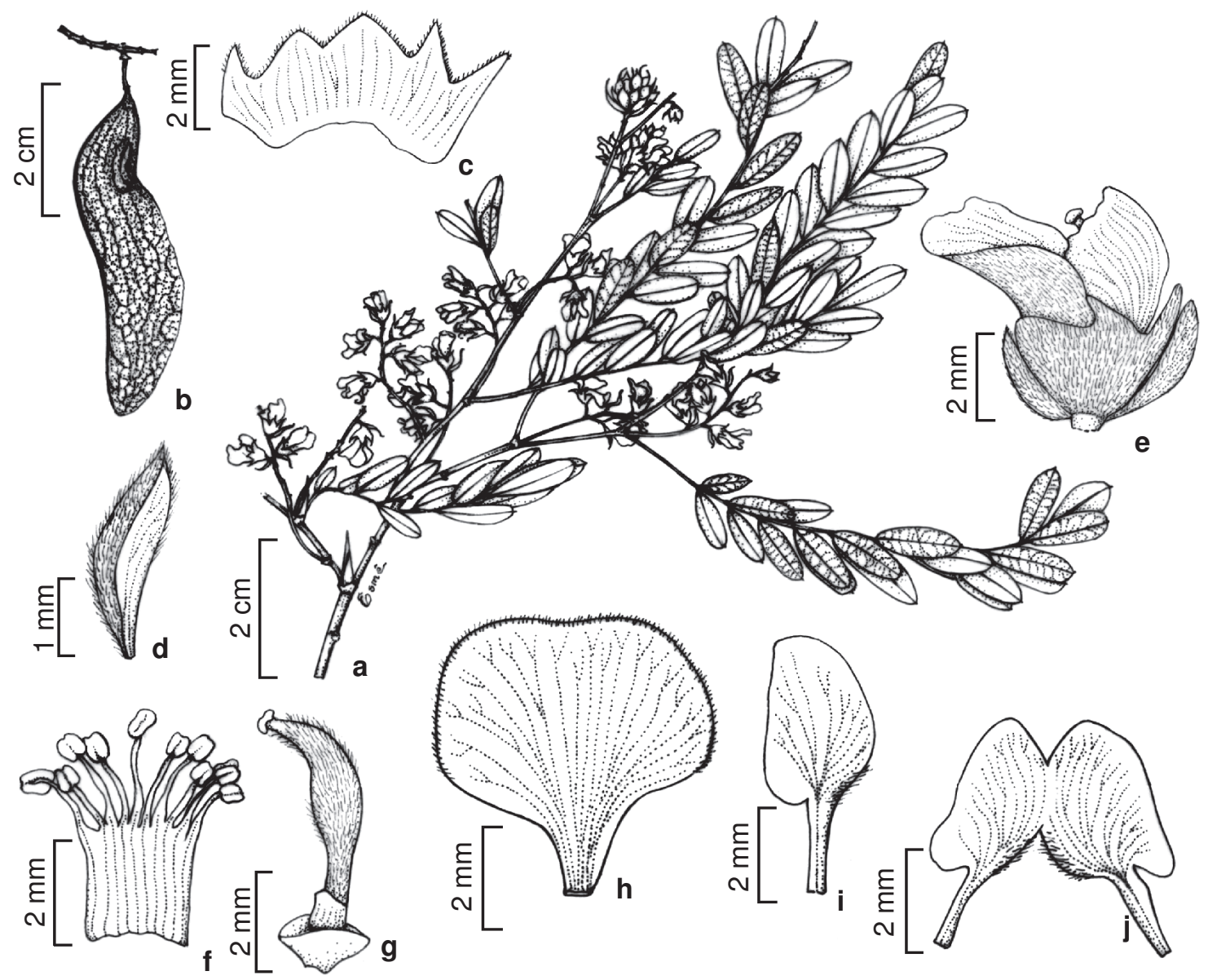

Figura 4 - Machaerium hatschbachii Rudd - a. ramo e inflorescência; b. fruto; c. cálice; d. bractéola; e. flor em antese; f. androceu; g. gineceu; h. vexilo; i. asa; j. pétalas da carena. (a Maschio 220; b Ziller 814; c-1 Hatschbach 20347)

$2 \times 1 \mathrm{~mm}$, densamente ferrugíneo-seríceo a tomentoso; estipe 1-1,5 mm, ferrugíneo-seríceo a tomentoso; estilete $1 \mathrm{~mm}$ compr., glabro. Fruto 3-7 cm compr.; estipe $0,4-0,8 \mathrm{~mm}$ compr., esparsamente ferrugíneo-seríceo, glabrescente; núcleo seminífero $1-2,2 \times 0,7-1,7(-2,4) \mathrm{cm}, 2 \mathrm{~mm}$ diâm., esparsamente ferrugíneo-puberulento a glabro, superfície reticulada, 4 nervuras longitudinais, prolongadas em direção a asa, fibroso; asa 3-4,5 × (0,8-) $1-1,3 \mathrm{~cm}$, falcada, formando com o núcleo seminífero ângulo maior que $90^{\circ}$, castanho clara a escura, concolor, esparsamente ferrugíneo-puberulenta a glabra, lisa, reticulada, cartácea, ápice obtuso a apiculado, margem plana a encurvada.

Material examinado: BRASIL. PARANÁ:Antonina, Cacatu, 20.XI.1968, fl., G. Hatschbach 20347 (C, M, MBM, MO, NY, UC, UEC, US, WAG); Campina Grande do Sul, Sítio do Belizário, G. Hatschbach
16280 (L!, MBM!, NY!, SI, US!, PARÁTIPOS); Cerro Azul, Morro Grande, G. Hatschbach 6390 (C!, LP!, MBM!, UPCB!, US!, WAG!, PARÁTIPOS); Dr. Ulysses, na divisa com Cerro Azul, 6.X.1999, fr., C.V. Mendonça \& G. Hatschbach 521 (BHCB, UEC); Guaraqueçaba, Rio do Cedro, G. Hatschbach 18117 (CEPEC!, F!, K!, MBM!, NY!, US, PARÁTIPOS); Guaraqueçaba, Serrinha, 1.VI.1967, fr., G. Hatschbach 16506 (L!, MBM!, SI, PARÁTIPOS); Guaratuba, Rio Itararé, G. Hatschbach 15118 (C!, F!, L!, P, SI, MBM!, NY!, UC!, US!, WAG, PARÁTIPOS); Piraquara, Campininha, G. Hatschbach 2652 (LP!, MBM!, SI, PARÁTIPOS); SÃO PAULO: Cananéia, Ilha do Cardoso, 5.XII.1990, fl., F. Barros \& J. E. L. S. Ribeiro 2025 (SP); São Vicente, Morro do Japu, 3.III.1991, fl., F. S. Santos 24205 (UEC).

Fenologia: floração de novembro a março e frutificação de dezembro a junho.

Hábitat e distribuição geográfica: floresta costeira, floresta de araucária. BRASIL: São 
Paulo e Paraná. As citações para o estado de São Paulo são inéditas para a espécie, que era conhecida apenas para o estado do Paraná. Nome popular: "jacarandá-de-espinho".

A espécie distingue-se de $M$. floridum, M. nyctitans, $M$. scleroxylon e $M$. ruddianum pelo tronco com casca escamosa, acinzentada, pelo estigma amplamente captado e pelos frutos geniculados. De M. nyctitans distingue-se pelo menor tamanho das flores e dos folíolos e pelas inflorescências menores, paucifloras, laxas, e assemelha-se no formato e revestimento de brácteas e bractéolas, estas geralmente do mesmo comprimento do cálice. Das outras espécies distingue-se pelas brácteas florais maiores e corola até 2,5 vezes o compr. do cálice. Diferencia-se de $M$. scleroxylon também pelas bractéolas lanceoladas, pelas flores menores, cálice liso, vexilo quase orbicular e pelos folíolos numerosos, mais revestidos, como também observado por Rudd (1973) e Sartori \& Tozzi (1998). De $M$. floridum e $M$. ruddianum distingue-se pelo porte maior, inflorescências mais curtas e pelas pétalas da carena com base fortemente auriculada. Os materiais citados para São Paulo representam a primeira referência da espécie para este estado.

\section{Machaerium myrianthum Spruce ex} Benth., J. Linn. Soc., Bot. 4 Suppl.: 59. 1860. In: Martius \& Eichler (eds.) Fl. bras. 15(1): 241. 1862. Typus: VENEZUELA: near Panuré, on the Rio Vaupés, I.1853, fl. e fr., R. Spruce 2758 (Holótipo K-Hb. Benth.!; Foto K: AMES!, C!, F!, NY!, S!, UEC!; Isótipos BM!, BR!, C!, F!, K!; Foto C: AMES!, MO!, Foto K: AMES!, F!, NY!, S!, UEC!).

Fig. 5

M. multifoliolatum Ducke, Bull. Mus. Hist. Nat. Paris, 2(5): 734-735. 1932; Arq. Jard. Bot. Rio de Janeiro 6: 34. 1933. Typus: BRASIL. AMAZONAS: Manaus, margem do igapó da cabeceira do iguarapé do Crespo, 17.XII.1929, fl., A. Ducke s.n. (Lectótipo RB!), syn. nov.

Liana; inerme, exsudato avermelhado. Ramos 2-3 mm diâm., superfície escamosa, glabros, às vezes lenticelados, com acúleos uncinados, $4 \times 1,5 \mathrm{~mm}$, quando novos fusco- puberulentos, ramos apreensores laterais com acúleos uncinados. Estípulas decíduas não observadas. Folhas 5-14 cm ×3-4 cm, 29-51 (-149)-folioladas; pecíolo 0,1-0,5 cm compr., 1 mm diâm., cilíndrico, fusco-puberulento a hípidotomentoso; raque 4,8-13 cm compr., 0,8 mm diâm., indumento como no pecíolo; peciólulo 0-0,4 mm compr. Folíolos alternos, (0,3-)0,6-2,8 $\times(0,1-) 0,3-0,7 \mathrm{~cm}$, linear-oblongos, ápice obtuso, levemente retuso, base cuneada a oblíqua, cartáceos, discolores, margens revolutas, espessadas, superfície adaxial glabra, superfície abaxial ferrugíneo-serícea a vilosa na nervura principal, glabrescente, venação broquidódroma. Panículas, 5-30 × 4-15 cm, terminais, laxas; pedúnculo $0-0,8 \mathrm{~cm}$ compr., $0,7 \mathrm{~mm}$ diâm.; raque 5-7,7 cm compr., fulvo a ferrugíneo-puberulenta; eixos laterais 2-5,6 cm compr., indumento como na raque. Brácteas $1-1,5 \times 0,5 \mathrm{~mm}$, triangulares a orbiculares, fulvo a ferrugíneo-puberulentas, cartáceas, às vezes decíduas. Flores sésseis a subsésseis, 5-7,3 mm compr., bractéolas 1,2$1,4 \times 0,5-1,4 \mathrm{~mm}$, oblongas a orbiculares, lisas, fulvo a ferrugíneo-seríceas, carnosas; cálice 2,53,3×2,5-2,8 mm, 2,4 mm diâm., superfície lisa, fulvo a ferrugíneo-serícea, carnoso, lacínios carenais triangulares, $0,8 \times 1 \mathrm{~mm}$, lacínios vexilares $0,5-1 \times 1-1,2 \mathrm{~mm}$, lobados; corola 2 vezes o compr. do cálice, pétalas esbranquiçadas a amareladas, com nervuras dicotômicas inconspícuas; vexilo 3,5-5,5 × 3-3,3 mm, cordiforme, superfície externa glabrescente, superfície interna glabra, carnoso, ápice fissurado, base auriculada, unha 1-1,5 mm compr.; asas 3,5-6,6 × 1,4-2 mm, oblongas, glabras, membranáceas, ápice obtuso, base auriculada, unha 1,4-2,7 mm compr.; pétalas da carena 4$6 \times 2 \mathrm{~mm}$, elípticas, conatas no dorso, glabras, membranáceas, ápice obtuso, base auriculada, unha 1,7-2,9 mm compr.; estames 10, semelhantes em compr. e tamanho, monadelfos; filetes 4,2$5,2 \mathrm{~mm}$ compr., glabros; anteras 0,2 $\times 0,2 \mathrm{~mm}$, oblongas; disco nectarífero $0,3-0,5 \times 0,3-0,8 \mathrm{~mm}$, cupulado; ovário estipitado, $1-2 \times 0,6-1 \mathrm{~mm}$, fulvo-seríceo, uniovulado; estipe $2-3 \mathrm{~mm}$ compr., glabro; estilete 1,4 mm compr., glabro; estigma levemente capitado. Fruto 5,5-7 cm compr.; 


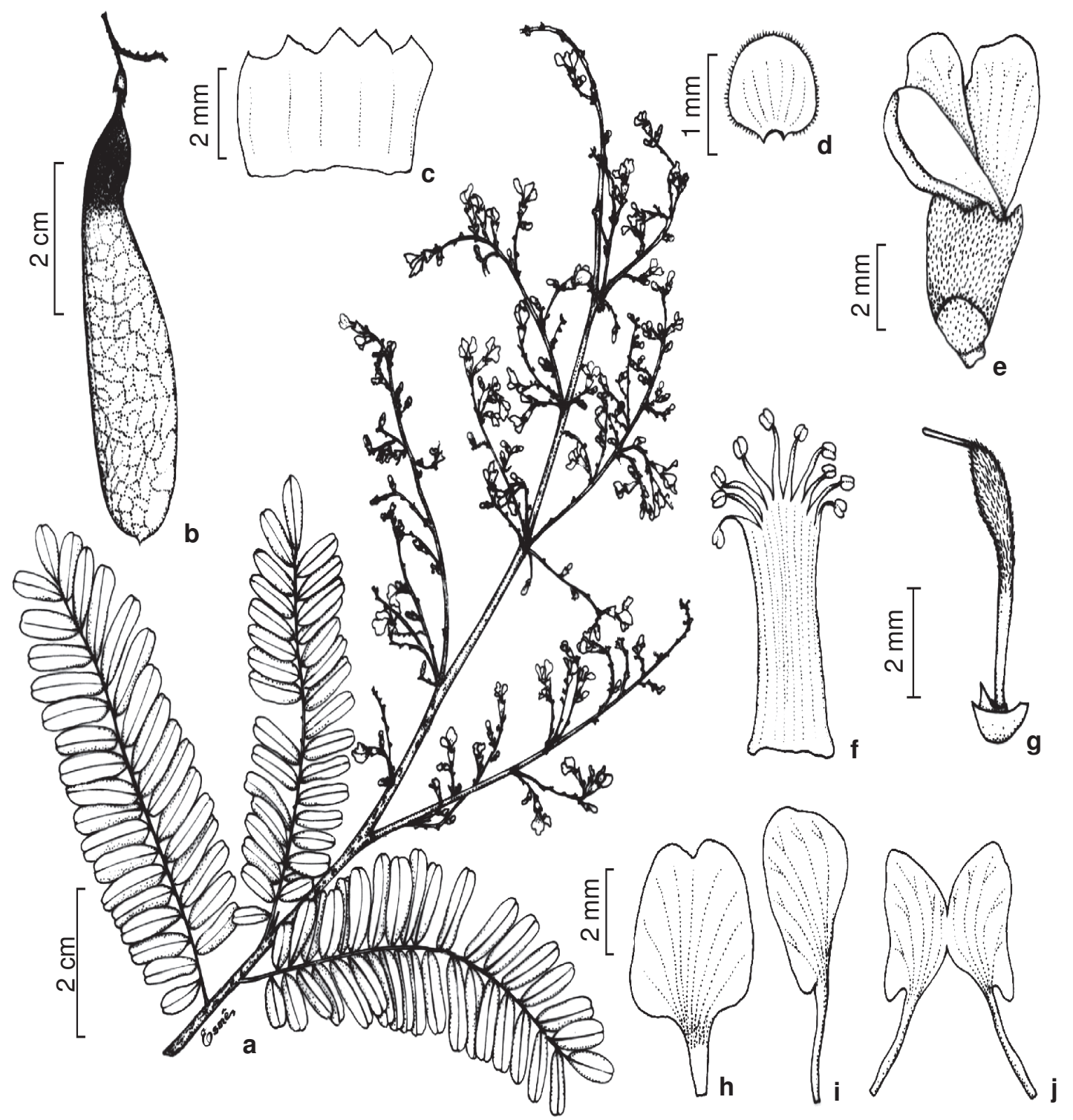

Figura 5 - Machaerium myrianthum Spruce ex Benth. - a. ramo e inflorescência; b. fruto; c. cálice; d. bractéola; e. flor em antese; f. androceu; g. gineceu; h. vexilo; j. asa; l. pétalas da carena. (a Liesner 7324; b Zarucchi 2430, c-1 Lasser 1940)

estipe 6-7 mm compr., fulvo-seríceo; núcleo seminífero $1,2-1,6 \times 0,6-0,7 \mathrm{~cm}$, castanhoescuro, fulvo-seríceo, superfície lisa, reticulada, fibroso; asa 3,4-4,5×1,3-1,5 cm, oblanceolada, com ângulo maior que $90^{\circ} \mathrm{em}$ relação ao núcleo seminífero, homogênea, fulvo-puberulenta, lisa, reticulada, cartácea, ápice obtuso, mucronulado, margem plana.

Material examinado: COLOMBIA. VAUPÉS: $3 \mathrm{~km}$ de Mitú, 4.VII.1979, fr., J. L. Zarucchi 2430 (AMES, U); GUIANA. Dadanawa, rio Rupununi, 14.VI.1922, fl., J. S. La Cruz 1500 (AMES, F, MO, NY, US);
DEMERARA: entre os rios Demerara e Berbice, 15.VII.1922. fl., J. S. La Cruz 1612 (AMES, F, MO, NY,UC); GUIANAFRANCESA. Cayenne, 15.II.1985, est., M. Sauvain 248(U); SURINAME.BROKOPONDO: 28.I.1966, est., J. van Donselaar 3082 (U); NICKERIE: 20.XI.1976, est., N. M. Heyde \& J. C. Lindeman 220 (U); VENEZUELA. BOLIVAR: IV.1956, fl., Vareschi \& Foldats $4529 b$ (NY); idem, entre Puerta Lema e a base da serra, 24.IX.1961, fr., J. A. Steyermark 89460 (NY); BRASIL. AMAZONAS: Cerro Neblina, Rio Mawarinuma, 20.IV.1984, est., A. Gentry \& B. Stein 46784 (MO, NY); MATO GROSSO: Tabajara, divisa com Rondônia, rio Machado, 
29.XI.1931, fl., B. A. Krukoff 1516 (AMES, BM, F, $\mathrm{K}, \mathrm{MO}, \mathrm{S}, \mathrm{NY}, \mathrm{UC})$; PARÁ: alto Tapajós, rio Cururu, 12.II.1974, fr., W. R. Anderson 10816 (IAN, NY); RORAIMA, estrada de Surucucu a Uaicá, Serra dos Surucucus, 6.II.1971, fl., G. T. Prance et al. 13518 (F, K, NY, S, U, WAG).

Fenologia: floração de outubro a julho e frutificação de dezembro a julho.

Hábitat e distribuição geográfica: floresta mesófila, igapó. Colômbia, Guiana, Guiana Francesa, Suriname, Venezuela. Brasil: Amazonas, Mato Grosso, Pará, Roraima.

Nome popular: "kabu-jasi-tatay (Suriname).

A observação da coleção típica de

M. multifoliolatum não deixou dúvidas sobre sua inclusão na sinonímia de $M$. myrianthum, principalmente quanto às características da inflorescência, demais detalhes florais e dos frutos. O menor tamanho e maior número dos folíolos descritos para M. multifoliolatum foram considerados uma variação populacional, não justificando seu reconhecimento como táxon distinto.

6. Machaerium nyctitans (Vell.) Benth., Comm. Legum. Gen.: 34. 1837; Ann. Mus. Vind. 2: 98. 1838, "nictitans". $\quad$ Fig. 6

Nissolia nyctitans Vell., Fl. fl. 295. 1829 11825ý; (Lectótipo: Fl. fl., Icon. 7: tab. 75. 1831 í1827ý; Epitipo, aqui designado: BRASIL. RIO DE JANEIRO: São Cristovão, 4.X.1878, fl., A. Glaziou 8404 (BR!; Isótipos C!, S!, NY!).

M. gardneri Benth., J. Linn. Soc., Bot., 4 Suppl.: 60. 1860. In: Martius \& Eichler (eds.). Flora bras. 15(1): 242. 1862. Typus: BRASIL. RIO DE JANEIRO: Rio de Janeiro, Serra dos Orgãos, IV.1837, fl., G. Gardner 357 (Holótipo K-Hb. Hook.!; Foto K: AMES!, F!, NY!, S!, UEC!; Isótipos K-Hb. Benth.!, BM!; Foto K: AMES!, F!, UEC!).

Machaerium nyctitans var. gardneri (Benth.) Rudd, Phytologia 26(2): 100 (1973).

M. sericiflorum Gardn. nom. ileg. In: Hook, Lond. Journ. Bot. 2: 341. 1843. non Vogel, 1837.

M. kuhlmannii Hoehne, Arq. Bot. Est. S. Paulo 1(1): 33. 1938. Typus: BRASIL. MINAS GERAIS: estrada que vai de Caratinga a EntreFolhas, 26.VII.1928, fr., J.G. Kuhlmann 50
(Lectótipo, aqui designado SPF; Isolectótipo RB; Síntipo: Viçosa, 24.X.1935, est., J. G. Kuhlmann s.n. RB, SPF, VIC). Syn. nov.

Árvore 5-25 m alt.; tronco reto, 6-57 $(-100)$ cm diâm., aculeado, acúleos 8-10×2 mm na base, casca escamosa, acinzentada, cerne creme, exsudato avermelhado, resinoso. Ramos 3-6 mm diâm., levemente sulcados, castanhoescuros, glabrescentes, lenticelados, espinescentes, acúleos piramidais, quando novos ferrugíneo-seríceos, glabrescentes, às vezes inermes. Estípulas 5-28 × 1-8 mm, lineares a triangulares, retas, espinescentes, às vezes decíduas. Folhas 8-18 ×3-6 cm, 13-29folioladas; pecíolo 0,8-2 cm compr., 1-6 mm diâm., hialino a fulvo-seríceo a ferrugíneoestrigoso a tomentoso, glabrescente; raque 4,8-8,2 cm compr., $1 \mathrm{~mm}$ diâm., indumento como no pecíolo; peciólulo 0,7-2 mm compr. Folíolos alternos, 1,5-4×0,6-2 cm, ápice obtuso a retuso, mucronulado, base arredondada, obtusa, cuneada, cartáceos, levemente discolores a concolores, margens planas a levemente revolutas, espessadas, superfície adaxial esparçamente hialino-vilosa, hialinopuberulenta na nervura principal, glabrescente, superfície abaxial fulvo a canescente-serícea a vilosa, venação broquidódroma. Racemos ou panículas 5-29×3-25 cm, do tamanho a até 5 vezes o comprimento das folhas, terminais, raro axilares, pêndulas, congestas, multifloras, às vezes com folhas entremeadas; pedúnculo (0-) 0,6-2 cm compr., 1-6 mm diâm.; raque (0-) 1,5-12 cm compr., canaliculada, flavo a ferrugíneopuberulenta, tomentosa, estrigosa a vilosa; eixos laterais 04-3,5 cm compr., ferrugíneo-seríceos, às vezes com tricomas esparsos, de base larga. Brácteas 2-4,7×1-2 mm triangulares, deltadas a ovadas, espinescentes, a lanceoladas, cimbiformes, carnosas, esparsamente flavo a ferrugíneo-seríceas a tomentosas, às vezes canescentes, a glabras. Flores sésseis a subsésseis, 7,8-12 mm compr.; pedicelo 0-1 mm compr., fulvo a a ferrugíneo-seríceo; bractéolas 3-5 $\times$ $0,5-1,5 \mathrm{~cm}$, falcadas a lanceoladas, cimbiformes, lisas, carnosas, canescente a ferrugíneoseríceas, às vezes com tricomas de base 


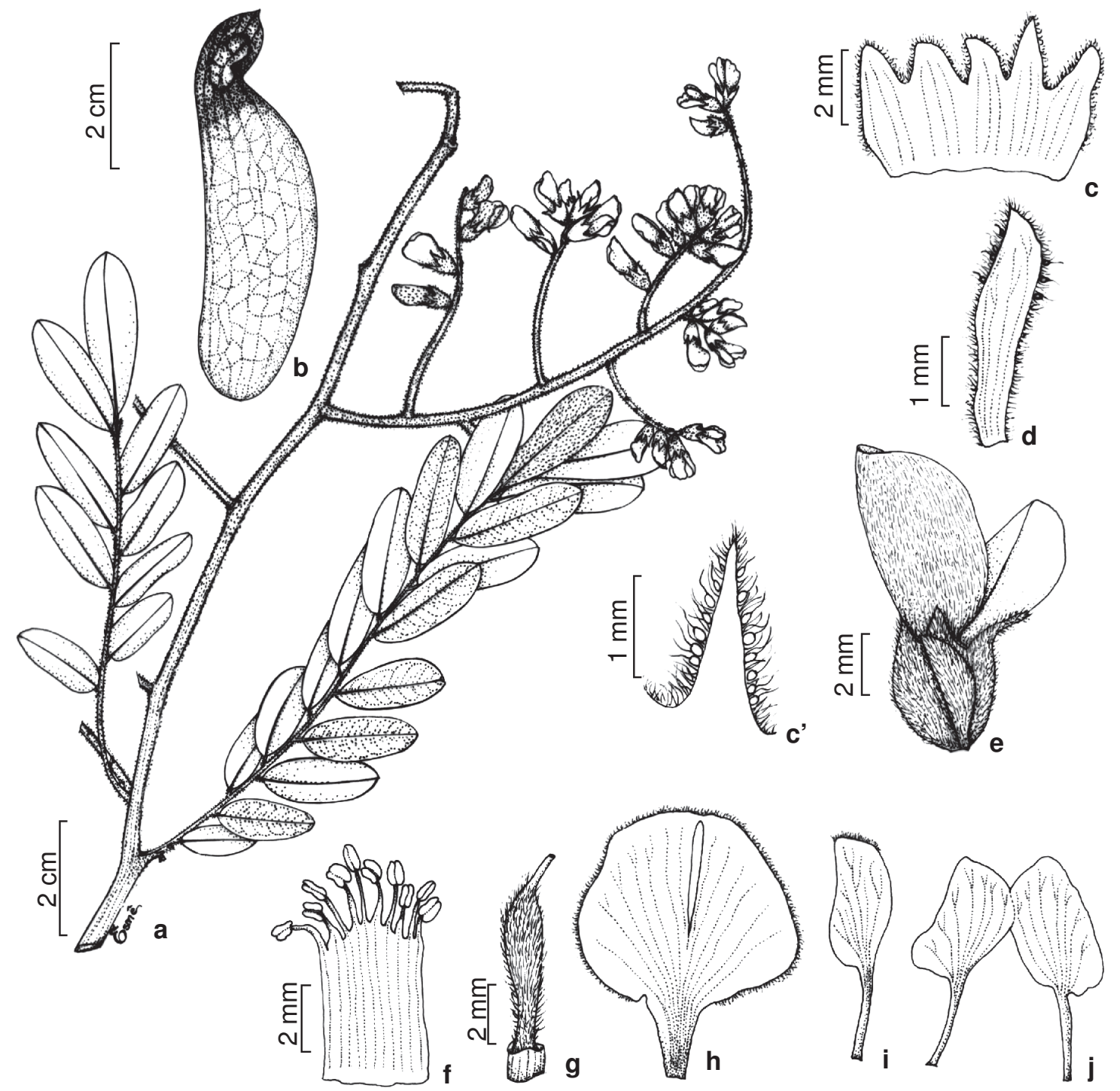

Figura 6 - Machaerium nyctitans (Vell.) Benth. - a. ramo e inflorescência; b. fruto; c. cálice; c'. lacínio; d. bractéola; e. flor em antese; f. androceu; g. gineceu; h. vexilo; i. asa; j. pétalas da carena. (a Mexia 4741; b Mendonça 428; c-1 Mexia 4724)

dilatada nas margens; cálice 3,7-6×2,2-3 mm, 2-3,7 mm diâm., campanulado a cilíndrico, superfície lisa, canescente, fulvo a ferrugíneoserícea, carnoso, lacínios com esparsos tricomas de base larga, os carenais $1-3 \times 0,5-1 \mathrm{~mm}$, triangulares a estreitamente triangulares, $\mathrm{o}$ central às vezes mais longo, os vexilares $0,8-$ $2,6 \times 0,5-1,6 \mathrm{~mm}$, triangulares a estreitamente triangulares; corola $2-2,5$ vezes o comprimento do cálice, pétalas vinosas, apresentando nervuras avermelhadas, dicotômicas, como as superfícies internas das bractéolas e do cálice; vexilo $6,4-10 \times 5-8 \mathrm{~mm}$, orbicular, internamente lilás, superfície externa fulvo-serícea, superfície interna fulvo a ferrugíneo-puberulenta a tomentosa na margem, carnoso, ápice retuso, às vezes mucronulado, base atenuada a auriculada, unha 1,3-2 mm compr.; asas 6,5-9 $\times 2-3 \mathrm{~mm}$, oblongas, glabras no dorso, membranáceas, ápice obtuso, fulvo a ferrugíneopuberulento a tomentoso, glabrescente, base levemente auriculada a truncada, unha 2,2$3,5 \mathrm{~mm}$ compr.; pétalas da carena $6,6-9 \times 2-$ $3 \mathrm{~mm}$, elípticas a oblongas, conatas, glabras a esparsamente ferrugíneo-seríceas no dorso, membranáceas, ápice agudo a obtuso, base 
auriculada a truncada, unha $2-4 \mathrm{~mm}$ compr.; estames 10, monadelfos, soldados 3-6 mm compr., às vezes diadelfos; filetes $4-8 \mathrm{~mm}$ compr., glabros a ferrugíneo-puberulentos a seríceos na margem da bainha; anteras $0,5-0,9 \times 0,2-$ $0,5 \mathrm{~mm}$, oblongas; disco nectarífero $0,5-1 \times$ 0,5-1,4 mm, cupulado; ovário estipitado, 2-4× 0,8-2 mm, flavo, fulvo a ferrugíneo-tomentoso a seríceo, uniovulado; estipe 1,5-4 mm compr., reto a encurvado na base, flavo a fulvotomentoso a seríceo; estilete 1,2-2,5 mm compr., glabro; estigma capitado. Fruto 5,3$8,2 \mathrm{~cm}$ compr.; estipe $0,5-0,9 \mathrm{~cm}$ compr., fulvo a ferrugíneo-seríceo a tomentoso; núcleo seminífero $1,4-1,7 \times 0,7-1 \mathrm{~cm}, 4,6-6 \mathrm{~mm}$ diâm., castanho-escuro, esparsamente fulvo a ferrugíneo-seríceo a tomentoso, glabrescente, superfície verrucosa, estriada, 3 a 6 nervuras principais prolongadas em direção a asa, fibroso; asa 4-4,7 × 1,3-2 cm, falcada a oblanceolada, apresentando ângulo menor que $90^{\circ}$ com o núcleo seminífero, homogênea, esparsamente hialino a ferrugíneo-puberulenta a serícea, às vezes glabra, lisa, reticulada, cartácea, ápice obtuso, mucronulado, margem plana a levemente encurvada, semente 1,4-1,6 $\times 0,7-1 \mathrm{~cm}, 3 \mathrm{~mm}$ diâm., reniforme; embrião com promórdios foliares pluripinulados.

Material examinado: ARGENTINA. MISSIONES: San Pedro, 26.IX.1945, fr., Bertoni 2135 (BM, F, K); CORRIENTES: San Tomé, 8.IV.1992, fl., S. G. Tressens et al. 4018 (AMES, C, CTES, F, MBM, MO, NY, UB); idem, 27.VIII.1992, fr., M. Pompert 43 (AMES, C, CTES, F, MBM, MO, NY, UB). BRASIL. BAHIA: Almadina, 2.III.1971, fl., R. $S$. Pinheiro 1110 (CEPEC, US); Ilhéus, distrito de Rio do Engenho, Faz. Theobroma, 1.VII.1995, fr., L. A. Mattos Silva 3151 (ALCB, CEPEC, NY); ESPÍRITO SANTO: Linhares, CVRD, 14.VIII.2001, fr., D. A. Folli 4001 (CVRD, UEC); MINAS GERAIS: Caratinga, estrada para Entre-Folhas, 1,5 km do trevo, 10.XI.1993, fr., C. V. Mendonça \& F. Garcia 304 (BHCB); Três Pontas, Faz. Jacarandá, 12.IV.1998, fl., C. V. Mendonça 428 (BHCB, SPF); PARANÁ: Antonina, Sapitanduva, 28.II.1969, fl., G. Hatschbach 21202 (M, MBM, NY, SPF, UB, UC, UPCB, WAG); Campina Grande do Sul, Jaguariaiva, 16.IV.1911, fl., P. Dusén 11658(F, MO, NY, S); Cerro Azul, 17.VII.1984, fr., G. Hatschbach
48085 (MBM); RIO DE JANEIRO: Itatiaia, 7.IV.1941, fl., W. D. Barros 256 (F, MO); Nova Friburgo, 6.III.1986, est., A. M. Carvalho \& H. C. Lima 2333 (CEPEC, HRB, IBGE, K, MBM, RB, UFBA); Rio de Janeiro, Jacarepaguá, 2.IV.1965, fl., J. P. L. Sobrinho 797 (IAC, L, NY, US); SÃOPAULO: Águas da Prata, 21.III.1994, fl., A. B. Martins et al. 31473 (UEC); Agudos, Faz. Sta. Rita, 24.III.1998, fl., P. F. A. Camargo \& P. F. A. Junior 528 (BAUR, UEC); Atibaia, 22.III.1988, fl., M. T. Grombone et al. 21451 (UEC).

Fenologia: floração de janeiro a outubro e frutificação de fevereiro a novembro.

Hábitat e distribuição geográfica: floresta costeira, floresta de araucária, Província Paranaense, em solo arenoso. Argentina: San Pedro, San Tomé. Brasil: Bahia, Minas Gerais Paraná, Rio de Janeiro e São Paulo.

Nomes populares: "bico-de-pato"; "jacarandábico-de-pato", "bico-de-pato-grande" "chimbé"; "tapa-tripa" (Brasil). "cuentrillo" (Argentina).

A ampla variação observada em $M$. nyctitans foi o que possivelmente levou Bentham (1860) a descrever M. gardneri, incluída na sinonímia de $M$. nyctitans por Hoehne (1941). Rudd (1973) não concordou com o último autor e estabeleceu uma combinação nova $M$. nyctitans var. gardneri (Benth.) Rudd, sendo portanto a primeira a reconhecer um táxon infra-específico. Entretanto, Rudd (com. pes., 1992) reconheceu a dificuldade de algumas vezes diferenciar as duas variedades. Outros autores têm indicado que o atual nível de conhecimento sobre a espécie sugere o uso de um conceito amplo, sem separação de táxons infra-específicos (Lima et al. 1994; Lima 1995; Sartori \& Tozzi 1998), conceito aqui adotado.

A designação do epitipo A. Glaziou 8404, proveniente do Rio de Janeiro, em associação à estampa apresentada por Vellozo na Flora Fluminensis (lectótipo da espécie) está em conformidade com o protólogo da espécie.

A inclusão de $M$. kuhlmannii na sinonímia desse táxon foi realizada após um cauteloso exame dos tipos e de coletas nas localidades típicas. Hoehne (1941) indicou que a ilustração das flores dessa espécie foi baseada em 
fragmentos dos frutos em desenvolvimento. A ilustração de uma bractéola orbicular, distinta daquela de $M$. nyctitans, possívelmente foi um equívoco na reconstituição da flor. A forma estreitamente triangular dos lacínios assemelhou-se àquela desse último táxon, corroborando a sinonimização de M. kuhlmannii.

$M$. nyctitans difere-se de $M$. floridum e M. scleroxylon pelo maior tamanho das folhas e da inflorescência, pelas flores lilases, pelo tamanho e forma das bractéolas e pelos frutos maiores. De M. hatschbachii distingue-se pelo tronco amarronzado, maior tamanho das folhas, folíolos, da inflorescência e das flores e também pelas estrias longitudinais no núcleo seminífero. Diferencia-se de M. ruddianum pelo revestimento hialino-viloso da superfície abaxial dos folíolos e ferrugíneo-tomentoso das inflorescências, bractéolas e cálice, pelas inflorescências ramificadas, bractéolas e flores maiores, pela presença de tricomas de base dilatada no cálice e nas bractéolas, pelo estipe mais longo, além de frutos, quando imaturos, com asa avermelhada, distinta do núcleo seminífero que é verde. Diferencia-se de M. ovalifolium pelo tronco escamoso, sem despregar placas, presença de tricomas de base larga nos lacínios do cálice, gineceu com estipe mais longo e estilete mais curto. Desta três últimas espécies difere também pelo núcleo seminífero com nervuras longitudinais que se prolongam na asa.

Estudos cromossômicos com M. nyctitans (Mendonça Filho et al. 2002), indicaram que esta espécie é tetraplóide, apresentando número cromossômico $2 n=40$. Segundo Guerra (1988) espécies poliplóides normalmente apresentam uma ampla distribuição, o que está de acordo com o observado nessa espécie.

7. Machaerium obovatum Kuhlm. \& Hoehne, Arq. Bot. Estado São Paulo 1(1): 34. 1938. Typus: BRASIL. RIO DE JANEIRO: Cabo Frio, X. 1899, fl., E. Ule s.n. (Holótipo R).

Fig. 7

Arbusto a árvores até $6,5 \mathrm{~m}$ alt. Tronco aculeado, acúleos $1-3 \times 0,5-1 \mathrm{~cm}$ na base, piramidais, casca lisa, acinzentada, lenticelada.
Ramos 4-5 mm, sulcados, acinzentados, glabros, lenticelados, espinescentes, quando novos glabros. Estípulas 2,5-6(-23) ×0,6-1,4 $(-5) \mathrm{mm}$, triangulares, retas, membranáceas, estriadas, a espinescentes, persistentes. Folhas 4,5-7,7×2,3-3,6 cm, 9-11-folioladas; pecíolo 1-1,3 cm compr., 0,6 mm diâm., cilíndrico, esparsamente fulvo-seríceo a glabro; raque 1,5-3,5 cm compr., 0,7 mm diâm., sulcada, glabra; peciólulo $1 \mathrm{~mm}$ compr., glabro. Folíolos alternos 1,2-3,7 ×0,6-1,7 cm, ápice retuso, base cuneada, oblíqua a cordata, cartáceos, concolores, oliváceos, margens inteiras, espessadas, superfícies adaxial e abaxial glabras, venação broquidódroma. Racemos ou panículas, $2-5,5 \times 1,5-3 \mathrm{~cm}$, do tamanho das folhas ou menores, axilares ou terminais, pêndulas, laxas; pedúnculo $0-0,8 \mathrm{~cm}$ compr., $1 \mathrm{~mm}$ diâm.; raque $1-4,2 \mathrm{~cm}$ compr., fuscotomentosa; eixos laterais $1,3-3,5 \mathrm{~cm}$ compr., indumento como na raque. Brácteas $5 \times 1 \mathrm{~mm}$, triangulares, glabras, espinescentes, às vezes decíduas. Flores pediceladas, $8 \mathrm{~mm}$ compr., pedicelo $2 \mathrm{~mm}$ compr., ferrugíneo-híspido; bractéolas $4,7 \times 1 \mathrm{~mm}$, cimbiformes, ferrugíneoestrigosas, carnosas; cálice $5 \times 2 \mathrm{~mm}, 2 \mathrm{~mm}$ diâm., cilíndrico, superfície lisa, fusco-tomentosa a ferrugíneo-serícea, carnoso, lacínios carenais $1,4-1,6 \times 0,7-1 \mathrm{~mm}$, estreitamente triangulares, lacínios vexilares $1,6-2 \times 1,2-1,4 \mathrm{~mm}$, triangulares; corola 2 vezes o compr. do cálice, lilás, pétalas com nervuras dicotômicas, como também as superfícies internas das bractéolas e cálice; vexilo $8,6 \times 7 \mathrm{~mm}$, orbicular, superfície externa fusco-serícea, superfície interna fuscopuberulenta na margem, carnoso, ápice levemente retuso, base auriculada, unha 2$6 \mathrm{~mm}$ compr.; asas 7,3 $\times 2,5 \mathrm{~mm}$, oblongas, membranáceas, ápice obtuso, base levemente auriculada, unha $3 \mathrm{~mm}$ compr.; pétalas da carena $7 \times 2,5 \mathrm{~mm}$, elípticas, conatas, glabras, membranáceas, ápice agudo, base auriculada, unha $3 \mathrm{~mm}$ compr.; estames diadelfos, semelhantes em compr. e tamanho, os centrais um pouco maiores que os laterais, soldados a 2,5-4 mm compr.; filetes 5-6,5 $\mathrm{mm}$ compr., glabros; anteras $0,5 \times 0,5 \mathrm{~mm}$, oblongas; disco 


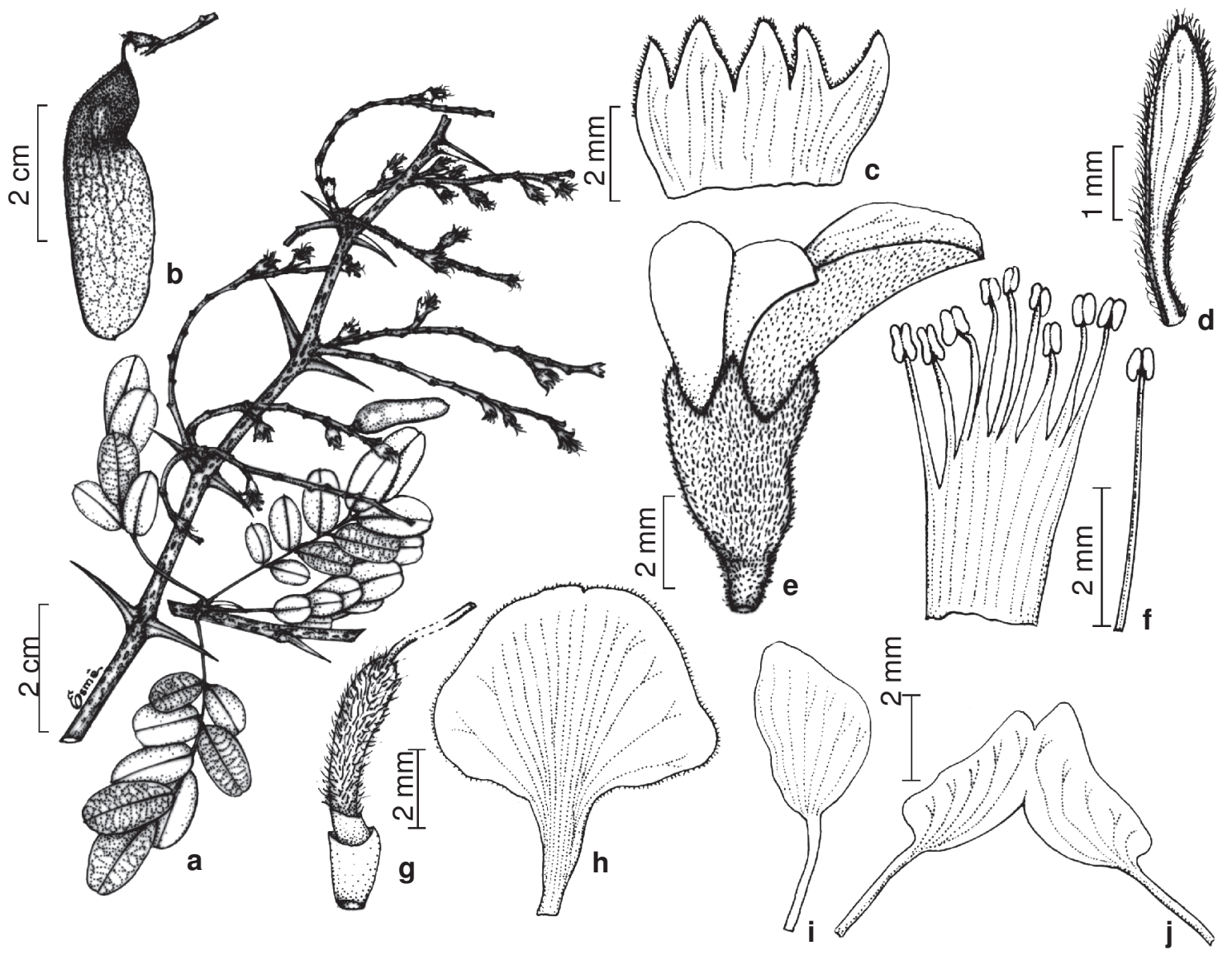

Figura 7 - Machaerium obovatum Kuhlm. \& Hoehne - a. ramo e inflorescência; b. fruto; c. cálice; d. bractéola; e. flor em antese; f. androceu; g. gineceu; h. vexilo; i. asa; j. pétalas da carena. (a, c-1 Mendonça 471, b. Lima 2695)

nectarífero $0,5 \times 0,5 \mathrm{~mm}$, cupulado; ovário estipitado, $2 \times 1 \mathrm{~mm}$, fulvo-seríceo a ferrugíneohirsuto, uniovulado; estipe $1,5 \mathrm{~mm}$ compr., ferrugíneo-seríceo; estilete $1 \mathrm{~mm}$ compr., glabro; estigma capitado. Fruto 3,5-5 cm compr.; estipe $0,4-0,6 \mathrm{~cm}$ compr., fulvoseríceo; núcleo seminífero $1-1,3 \times 0,7-0,8 \mathrm{~cm}$, 2,5-3 mm diâm., castanho-escuro, fulvoseríceo a ferrugíneo-puberulento, às vezes com tricomas de base dilatada esbranquiçados, superfície lisa, reticulada, fibroso; asa 2,5-3,3 $\times 1-1,3 \mathrm{~cm}$, oblonga, formando ângulo menor que $90^{\circ}$ em relação ao núcleo seminífero, homogênea, esparsamente fulvo a ferrugíneoserícea, glabrescente, lisa, reticulada, cartácea, ápice obtuso a agudo, apiculado, margens planas; semente $1,2 \times 0,6 \mathrm{~cm}$; testa avermelhada, ruminada, embrião com promórdios foliares pluripinulados.

Material examinado: RIODE JANEIRO: Cabo Frio, 29.VIII.1986, fr., H. C. Lima et al. 2695 (MBM, NY,
$\mathrm{RB})$; idem, estrada para a praia das conchas, 5.IX.1999, fl., C. V. Mendonça 467 (BHCB, UEC); idem, morro do canal, 7.IX.1999, fl. e fr., C. V. Mendonça 471 (BHCB, UEC); idem, lagoa de Araruama, 3.XI.1993, fr., B. B. Klitgaard \& H. C. Lima 3 (NY, RB, U).

Fenologia: floração de agosto a setembro e frutificação de agosto a novembro.

Hábitat e distribuição geográfica: mata seca sobre colinas litorâneas, em solo arenoso, pedregoso. Restrita ao Rio de Janeiro.

Essa espécie assemelha-se bastante a M. ovalifolium, principalmente quanto ao tronco acinzentado, com acúleos piramidais também observado nessa espécie, principalmente em populações que ocorrem em solos arenosos, rochosos nas áreas de caatinga do norte de Minas Gerais e na Bahia. Diferencia-se desta pelo porte menor, pelas folhas e folíolos menores, glabros, pelo estilete mais curto e frutos menores. 
8. Machaerium ovalifolium Glaz. ex Rudd, Phytologia 24(2): 124. 1972. Typus: BRASIL. MINAS GERAIS: Carandahy, 4.VI.1882, fl., A.F.M. Glaziou 13710 (Holótipo P; Isótipos C!, G!, K!).

Fig. 8

M. ovalifolium Glaz., Bull. Soc. Bot. France, Mem 3: 147. 1906, nom. nud.

M. ovalifolium Glaz. ex Hoehne, Fl. brasilica 25(3): 37. 1941, nom. nud.

Árvore, 5-18 m alt. Tronco reto, 15$30 \mathrm{~cm}$ diâm., acúleos 2-2,5 × 0,3-1,5 cm, triangulares, cerne creme, exsudato avermelhado, casca lisa, acinzentada na planta jovem e nos rebrotos, lenticelas horizontais, na planta adulta escamosa, despregando placas longitudinais, amarronzada. Ramos 3,5-5 mm diâm., sulcados longitudinalmente, acinzentados, glabros, lenticelados, espinescentes, quando novos ferrugíneo a fulvo-seríceos a glabros. Estípulas 10-30×3-4 mm, triangulares, retas, espinescentes, persistentes. Folhas (7-)1115 -folioladas, $8-14 \times 3,5-7,5 \mathrm{~cm}$; pecíolo 0,8-2 cm, $1 \mathrm{~mm}$ diâm., cilíndrico, sulcado, ferrugíneo a fulvo-seríceo; raque 4,5-8 cm compr., $1 \mathrm{~mm}$ diâm., cilíndrica, indumento como no pecíolo; peciólulo $1 \mathrm{~mm}$ compr. Folíolos alternos, 2,5-4,5 × 1-2 cm, ápice obtuso, mucronulado, base obtusa, cordada a cuneada, cartáceos, discolores, margens revolutas, espessadas, superfície adaxial glabra, superfície abaxial hialino a fulvo-serícea na nervura principal a glabra, venação broquidódroma. Racemos ou panículas, 3,59,5 × 3-4 cm, axilares ou terminais, flores congestas; pedúnculo $0-1,8 \mathrm{~cm}$ compr., $1,5 \mathrm{~mm}$ diâm.; raque 2,5-9 cm compr., fulvo-serícea a tomentosa, lenticelada, eixos laterais $1,5-7 \mathrm{~cm}$ compr., indumento como na raque. Brácteas (1-)4-8 $\times 2-6 \mathrm{~mm}$, lanceoladas a orbiculares, fulvo-seríceas a glabras, membranáceas a espinescentes. Flores sésseis a subsésseis, $7-$ $10 \mathrm{~mm}$ compr.; bractéolas 3-4 × 1-2 mm, oblanceoladas, côncavas, lisas, ferrugíneoseríceas, carnosas; cálice 3,5-5 × 2-3,5 cm, 2-3 mm diâm., campanulado, liso, fulvoseríceo, carnoso, lacínios carenais $1-2 \times 1 \mathrm{~mm}$, triangulares, lacínios vexilares $0,8-1 \times 2 \mathrm{~mm}$, lobados a triangulares; corola $2-3$ vezes o compr. do cálice, pétalas lilases a avermelhadas, apresentando nervuras avermelhadas, dicotômicas, como também as superfícies internas das bractéolas e do cálice; vexilo 5,5-8 × 7-7,5 mm, orbicular, superfície externa fulvo-serícea, superfície interna glabra, carnoso, ápice mucronulado, base auriculada, unha 1-2,5 cm compr.; asas $7-9 \times 2-2,5 \mathrm{~cm}$, elípticas a oblongas, membranáceas, ápice obtuso a agudo, fulvotomentoso, base auriculada, unha $2-2,5 \mathrm{~mm}$ compr.; pétalas da carena 7-8,5 $\times 2-3 \mathrm{~mm}$, falcado-elípticas, conatas no dorso, glabras, membranáceas, ápice agudo, base auriculada, unha $2-2,5 \mathrm{~mm}$ compr.; estames 10 , monadelfos, às vezes diadelfos; filetes 5$7 \mathrm{~mm}$ compr., glabros; anteras $0,5 \times 0,5 \mathrm{~mm}$, oblongas; disco nectarífero $0,5-1 \times 0,6-1 \mathrm{~mm}$, cupulado; ovário estipitado, 2,5-3 × $1 \mathrm{~mm}$, fulvo-seríceo, uniovulado; estipe $1 \mathrm{~mm}$ compr., hialino a fulvo-seríceo; estilete $3-3,5 \mathrm{~mm}$ compr., glabro; estigma levemente capitado. Fruto 4-7,2 cm compr.; estipe 0,5-0,7 cm compr., fulvo-seríceo; núcleo seminífero 11,5 × 0,8-1 cm, 4-6 mm diâm., castanhoescuro, esparsamente fulvo-puberulento a seríceo, reticulado, verrucoso, fibroso; asa $2,5-5,5 \times 1,3-1,8 \mathrm{~cm}$, oblanceolada a falcada, apresentando ângulo de $90^{\circ}$ em relação ao núcleo seminífero, homogênea, glabra, lisa, reticulada, cartácea, ápice obtuso, margem plana; semente $1-1,4 \times 0,7-0,8 \mathrm{~cm}$, reniforme; testa castanho-clara, ruminada.

Material examinado: BRASIL. BAHIA: Abaíra, 31.VII.1992, fr., W. Ganeo 799 (SPF); Almadina, rodovia para Ibitupã, 12.III.1971, fr., R. S. Pinheiro 1142 (CEPEC); Itajú da Colônia, 23.I.1969, fl., T. S. Santos 344 (CEPEC, NY, US); ESPÍRITO SANTO: Linhares, CVRD, 26.III.1973, fl., J. Spada 226 (US); idem, 21.IX.2000, fr., C. V. Mendonça \& D. A. Folli 601 (CVRD, UEC); MINAS GERAIS: Almenara, 18.VII.1988, fr., G Hatschbach et al. 52204 (C, CEPEC, K, MBM, MO, US); Coronel Murta, beira do Rio Jequetinhonha, V.1997, fr., E. T. Neto 2511 (BHCB); Itaobim, Vale do Jequetinhonha, 14.VI.1986, fr., $G$. Hatschbach \& J. M. Silva 50395 (C, K, MBM, UC). 


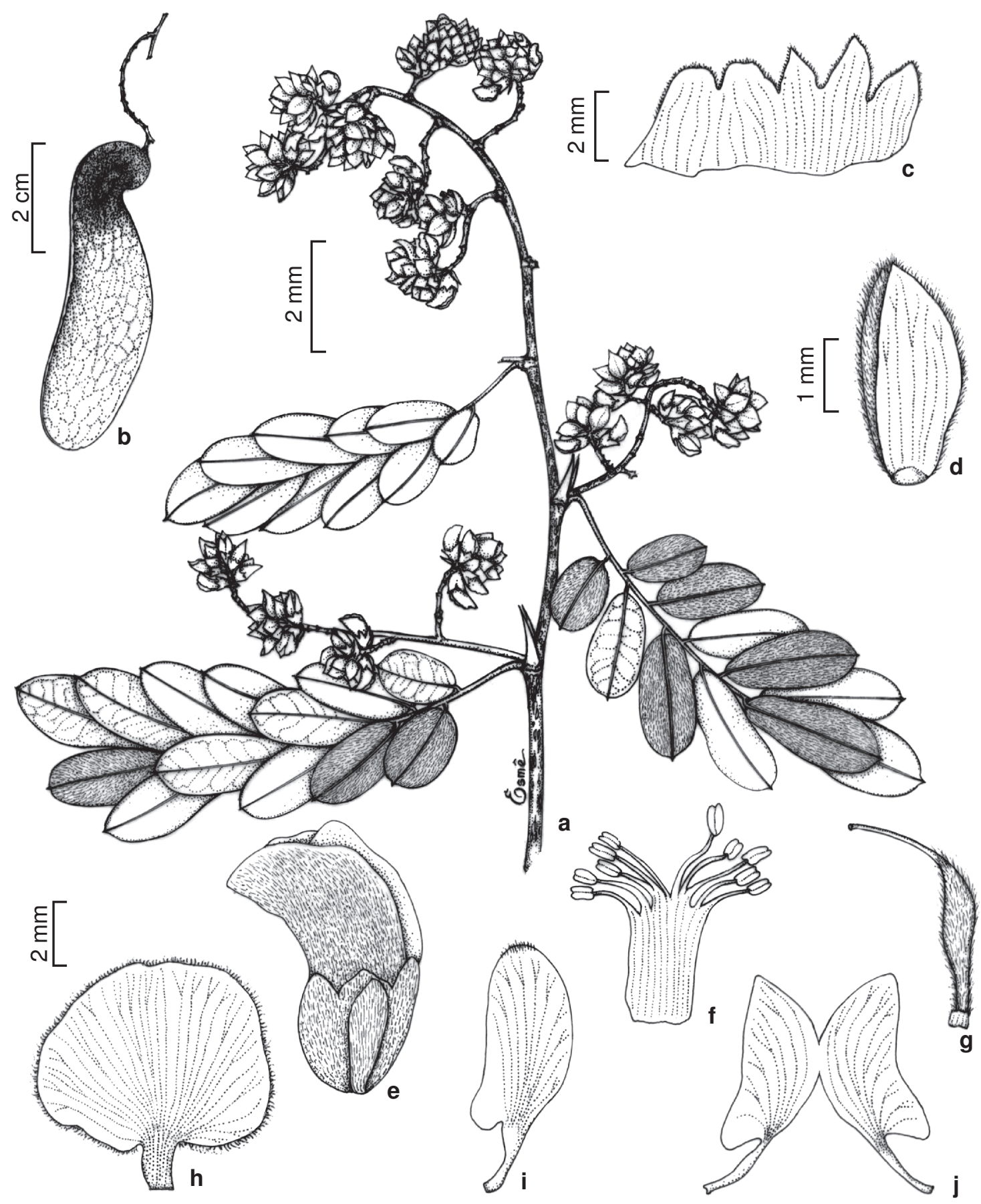

Figura 8 - Machaerium ovalifolium Glaz. ex Rudd - a. ramo e inflorescência; b. fruto; c. cálice; d. bractéola; e. flor em antese; f. androceu; g. gineceu; h. vexilo; i. asa; j. pétalas da carena. (a Glaziou 13710; b Mendonça 601; c-1 Spada 226) 
Fenologia: floração de dezembro a maio e frutificação de janeiro a setembro.

Hábitat e distribuição: floresta costeira, hiléia bahiana, caatinga arbustiva densa, em solo arenoso, pedregoso. BRASIL: Bahia, Espírito Santo e Minas Gerais.

Nome popular: "bico-de-juritî" (MG), "bicode-pato", "jacarandá-cipó” (ES).

O tamanho dos indivíduos, indumento, consistência e número de folíolos e coloração dos frutos são caracteres bem variáveis em M. ovalifolium e estão possivelmente relacionadas com as condições edáficas e climáticas. Em regiões mais úmidas, como em Carandaí-MG (localidade típica) e em Linhares-ES, os indivíduos são mais altos, as folhas apresentam maior número de folíolos, que são mais estreitos e bastante revestidos na face abaxial e os frutos apresentam asa estreita e coloração castanha. Na caatinga ou em matas secas ao norte de Minas Gerais e na Bahia as árvores são menores, as folhas apresentam menor número de folíolos, que são mais largos, glabros e os frutos possuem asa mais larga, amarelada. Os caracteres florais observados, entretanto, são suficientes para reconhecer estas populações como parte de uma única espécie.

A espécie apresenta grande afinidade com M. nyctitans da qual diferencia-se pelo tronco esfoliante, desprendendo placas longitudinais, ausência de tricomas de base larga nos lacínios do cálice, gineceu com estipe mais curto e estilete mais longo e pelo núcleo seminífero sem estrias longitudinais. Diferencia-se de $M$. obovatum pelo porte maior e folíolos mais largos e também pelas características do tronco, que nesta espécie apresenta acúleos piramidais. Diferenciase de $M$. tortipes pelas asas, pétalas da carena e ovário menores, androceu monadelfo e núcleo seminífero mais estreito e também pelo gineceu com estipe mais curto e estilete mais longo.
9. Machaerium ruddianum C.V. Mend. F. \& A.M.G. Azevedo, stat. \& nom. nov.

Fig. 9

Drepanocarpus floridus var. parviflorus Benth. In: Martius \& Eichler (eds.). Fl. bras. 15(1): 257. 1862. Typus: BRASIL. RIO DE JANEIRO: in silvis montis Corcovado et alibi prope Rio de Janeiro, C.P. von Martius 158 (Lectótipo, aqui designado BR!; Isolectótipos F!, K-Hb. Benth.!, K-Hb. Hook.!, L!, M; Foto K: AMES!, F!, FI, NY!, S!, UEC!; Síntipo: Brasil, Rio de Janeiro, 1839, fl., J.B.A. Guillemin s.n. K-Hb. Benth.!; Foto K: UEC!).

Drepanocarpus floridus Mart. nom. ileg., Flora 20(2): 118. nov. 1837., non Mart. ex Benth., jun. 1837.

Machaerium floridum var. parviflorum (Benth.) Hoehne, Fl. brasilica 128: 69. 1941.

Árvore 5-15 m alt. Tronco reto, 6-10 cm diâm., acúleos 8-10 × $2 \mathrm{~mm}$, lineares, casca lisa, acinzentada, lenticelada, cerne creme, exsudato ausente. Ramos 2-5 mm diâm., sulcados, esbranquiçados, acinzentados a enegrecidos, glabros, lenticelados, espinescentes, quando novos esparçamente fulvo-puberulentos. Estípulas 3,4-12×1-3 mm, lineares a triangulares, retas, espinescentes, às vezes decíduas. Folhas 3,5-14(-20)×3,8-5 cm, 11-27-folioladas; pecíolo 0,5-2 cm compr., 1 mm diâm., fusco-puberulento, estrigoso a tomentoso, às vezes hialino-estrigoso; raque 4-12 cm, $1 \mathrm{~mm}$ diâm., indumento como no pecíolo; peciólulo 1-2 mm compr. Folíolos alternos, $1-3,5 \times 0,3-1,5 \mathrm{~cm}$, ápice obtuso, retuso, às vezes mucronulado, base arredondada, obtusa, cuneada a oblíqua, cartáceos, levemente discolores, margens inteiras, planas, espessadas, superfície adaxial esparsamente hialinoserícea, glabrescente, superfície abaxial hialinoserícea, ferrugíneo-puberulenta na nervura principal, venação broquidódroma. Panículas $2,8-15 \times 1,5-6 \mathrm{~cm}, 0,5$ a 3 vezes o comprimento das folhas, axilares ou terminais, laxas, multifloras; pedúnculo (0-) 0,5-2,3 cm compr., 0,5-1 mm diâm.; raque 2,5-17,5 cm compr., 


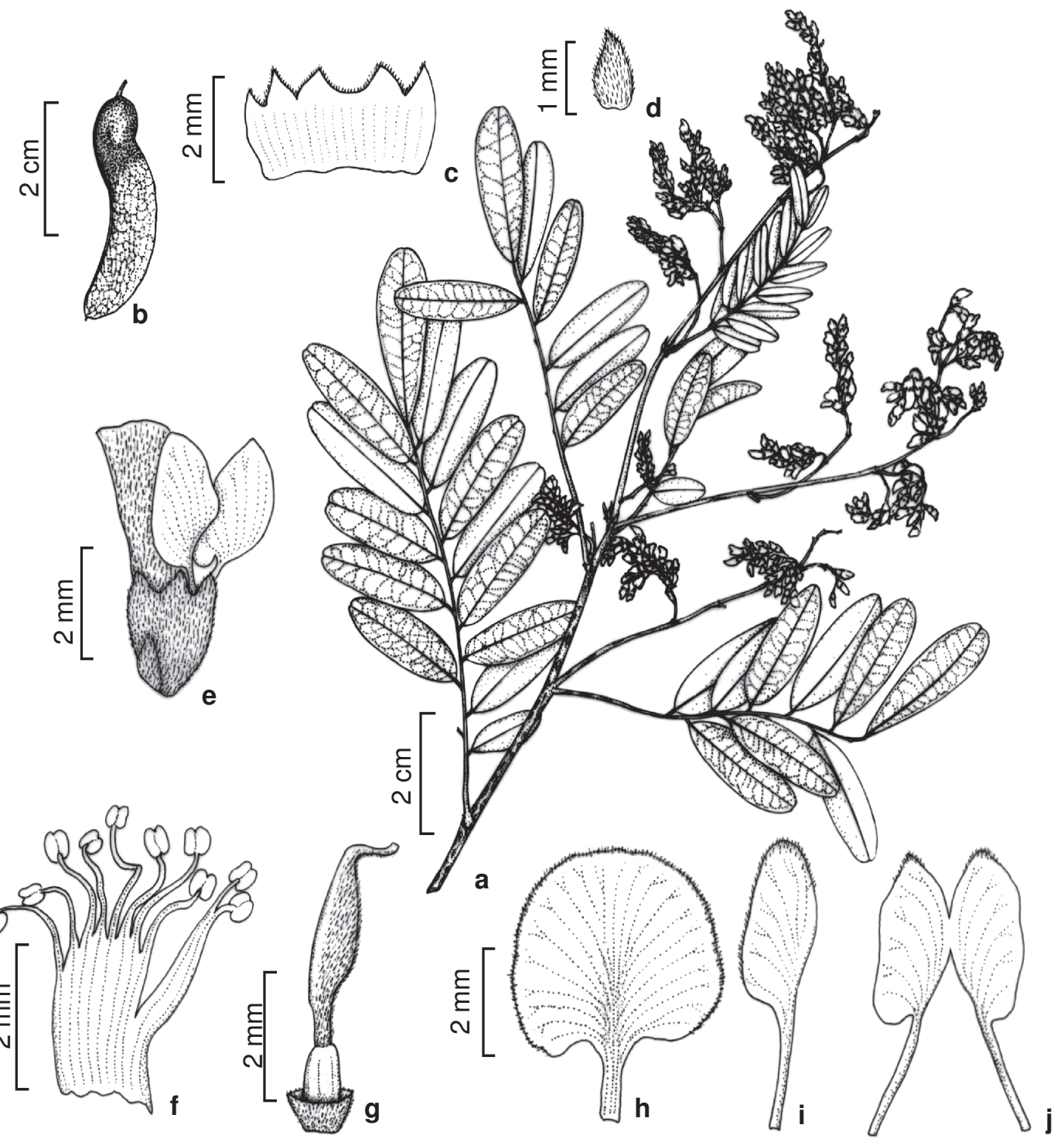

Figura 9 - Machaerium ruddianum C.V. Mend. F. \& A.M.G. Azevedo - a. ramo e inflorescência; b. fruto; c. cálice; d. bractéola; e. flor em antese; f. androceu; g. gineceu; h. vexilo; i. asa; j. pétalas da carena. (a, c-1 Duarte 4780; b Lima 3041)

fulvo a ferrugíneo-serícea a tomentosa; eixos laterais $0,8-5 \mathrm{~cm}$ compr., indumento como na raque. Brácteas $1-2,5 \times 0,5-2,7 \mathrm{~mm}$, triangulares, ovadas a orbiculares, às vezes côncavas; hialino a fulvo-puberulentas a seríceas, a ferrugíneo-tomentosas, papiráceas, rígidas a carnosas, decíduas. Flores subsésseis, 5-6,5 mm compr.; bractéolas 1-2,5 ×0,4-1 mm, ovadas, triangulares, cimbiformes, carnosas, lisas, ferrugíneo-seríceas a tomentosas; cálice 2-3,5 $\times 1,5-2,5 \mathrm{~mm}, 1,5-2 \mathrm{~mm}$ diâm., superfície lisa, ferrugíneo-tomentosa, lacínios carenais $0,5-1$ $\times 0,5-1 \mathrm{~mm}$, triangulares, lacínios vexilares $1 \times$ $1 \mathrm{~mm}$, triangulares; corola $2-3$ vezes o comprimento do cálice, pedicelo $0-0,5 \mathrm{~mm}$ compr., ferrugíneo-puberulento, pétalas com nervuras avermelhadas, dicotômicas, inconspícuas, como também as superfícies internas das bractéolas e do cálice; vexilo 4,5-5,5×4-5 mm, orbicular a oblado, superfície externa ferrugíneoserícea, superfície interna ferrugíneo-tomentosa na margem, ápice mucronulado, base levemente auriculada, unha 1-1,5 mm compr.; asas 5-6 $\times 1,5-2 \mathrm{~mm}$, oblongas, membranáceas, ápice 
obtuso, esparsamente ferrugíneo-seríceo, base levemente auriculada, unha $2 \mathrm{~mm}$ compr.; pétalas da carena 5-5,5 × 1-2 mm, elípticas, conatas no dorso, glabras, membranáceas, ápice agudo, base auriculada, unha 1,5-2 mm compr.; estames 10, monadelfos, às vezes diadelfos, soldados até $2-3 \mathrm{~mm}$ compr.; filetes 3-5 mm compr., glabros; anteras $0,5 \times 0,3 \mathrm{~mm}$, oblongas; disco nectarífero $0,4-1 \times 0,5 \mathrm{~mm}$, cupulado; ovário estipitado, 1,5-2×0,6-1 mm, ferrugíneo-seríceo, uniovulado; estipe $0,6-$ $1 \mathrm{~mm}$, ferrugíneo-seríceo; estilete 1-2 mm compr., glabro. Fruto 3-6 cm compr.; estipe 0,2-0,5 cm, ferrugíneo-seríceo; núcleo seminífero 1-1,5×0,7-0,8(-1) cm, 2 mm diâm., castanho-escuro, esparsamente ferrugíneoseríceo, superfície reticulada, fibroso; asa 1,6$4 \times 0,8-1,2 \mathrm{~cm}$, oblonga, apresentando ângulo menor que $90^{\circ}$ em relação ao núcleo seminífero, concolor, esparsamente ferrugíneopuberulenta, lisa, reticulada, cartácea, ápice obtuso, margens planas a encurvadas.

Material examinado: BRASIL. ESPÍRITO SANTO: Ibatiba, 21.III.1991, fr., D. A. Folli 1319 (CVRD, UEC); Santa Teresa, estr. São Lourenço até a Mata Fria, 18.IX.2000, est., C. V. Mendonça \& L. Kollmann 573 (MBML, UEC); MINAS GERAIS: Araguari, Parque John Kennedy, 9.V.1992, fr., G. M. Araújo et al. 896 (HUFU); Caratinga, Faz. Montes Claros, 23.III.1991, fr., C. V. Mendonça et al. 153 (BHCB); idem, frente ao laboratório de campo, 31.I.1998, fl. e fr., C. V. Mendonça 389 (BHCB, UEC); Mariana, beira do Rio Gualaxo, 5.IV.1998, fl., E. T. Neto 2708 (BHCB, UEC); PARANÁ: Teixeira Soares, IV.1908, fl., A. J. Sampaio 731 (R); RIODE JANEIRO: Rio de Janeiro, 19.V.1959, fl., A. P. Duarte \& E. Pereira 4780 (LP, RB); idem, Santa Teresa, Monte Corcovado, V.1839, fl., J. B. A. Guillemin 830 (F, K, NY, RB).

Fenologia: floração e frutificação de janeiro a julho.

Hábitat e distribuição geográfica: floresta mesófila, floresta costeira. Brasil: Espítio Santo, Minas Gerais, Paraná e Rio de Janeiro.

Nome popular: "bico-de ganso" (ES); "rabode bugio" (MG).

Ao considerar que Machaerium floridum var. parviflorum constitui uma espécie e não táxon infra-específico e que o nome Machaerium parviflorum já havia sido descrito por Bentham e desta forma não estava disponível, foi necessário designar um "nomem novum".

Drepanocarpus floridus Mart., publicado em novembro de 1837 e baseado em Martius 158, é um nome ilegítimo por ser homônimo de D. floridus Mart. ex Benth., espécie descrita com base em outra coleta de Martius procedente da Bahia e que tem prioridade por ter sido publicada anteriormente, em junho de 1837. O nome é uma homenagem à Dra. Velva E. Rudd pela sua importante contribuição à taxonomia de Machaerium.

Machaerium ruddianum difere-se de $M$. floridum pelo estilete mais curto, vexilo orbicular, pela bainha de estames e/ou pelo estame vexilar (quando presente) glabros, pelo disco nectarífero proeminente e estilete mais curto e assemelha-se pelo tronco acinzentado, lenticelado e pelas características das folhas. Diferencia-se de $M$. nyctitans pela ausência de tricomas de base glandular nos lacínios do cálice, pelas inflorescências mais ramificadas e esguias, estilete mais curto, bractéolas e frutos menores. As citações de $M$. ruddianum para o Espírito Santo, Minas Gerais e Paraná são inéditas.

10. Machaerium saraense Rudd, Phytologia, 24(2): 125. 1972. Typus: BOLÍVIA. SANTA CRUZ: Sará, "campos-region, Rio Palometillas" 400 m. elev., 21.XII.1924. fr., J. Steinbach 6788 (Holótipo F!; Isótipos BA!, BM!, G, K!, MO!, NY, S!, U, UC!, UEC- foto $\mathrm{K}$ !, W).

Fig. 10

Arbusto a árvore até $8 \mathrm{~m}$ alt. Tronco inerme. Ramos $3 \mathrm{~mm}$ diâm., superfície escamosa, esbranquiçada, lenticelados, glabros. Estípulas decíduas, não observadas. Folhas 4,5-7 × 3,5-4,5 cm, 9-13-folioladas; pecíolo 0,8-1,3 cm compr., 0,5 mm diâm., castanhoclaro, glabro; raque 3-5 cm compr., 0,5-1 mm diâm., sulcada, glabra; peciólulo 1-2 mm compr., glabro. Folíolos alternos, 1-2 $\times 0,5-$ $1,2 \mathrm{~cm}$, ápice obtuso, retuso, base arredondada a cuneada, membranáceos, discolores, margens revolutas, espessadas, superfícies adaxial e 


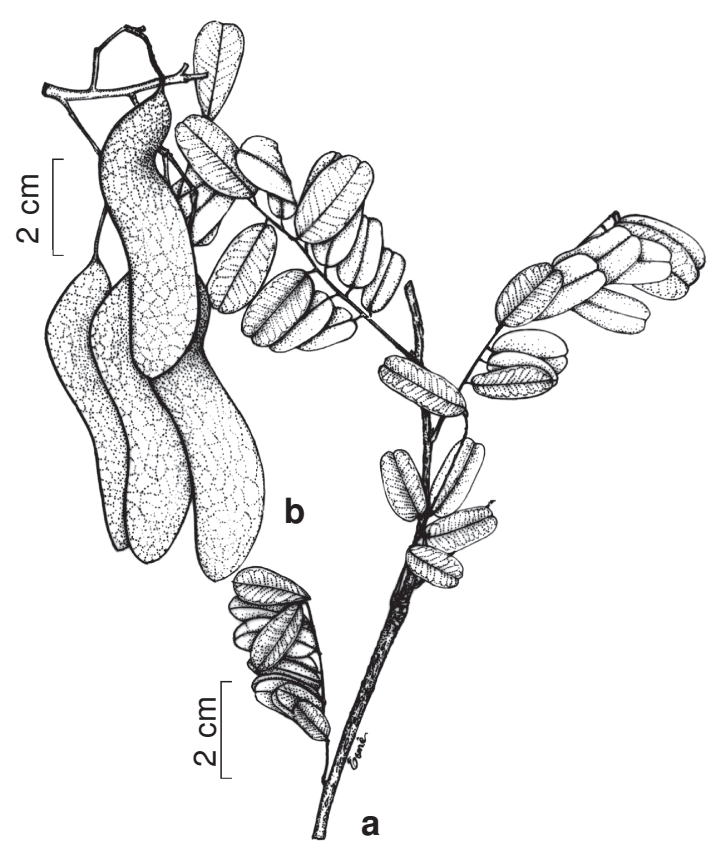

Figura 10 - Machaerium saraense Rudd - a. ramo; b. fruto. (a-b Guillén 1088)

abaxial glabras, venação broquidódroma. Inflorescência terminal ou axilar, pedúnculo e raque glabros. Brácteas e bractéolas não observadas. Flores $8 \mathrm{~mm}$ compr.; cálice $4-5 \mathrm{~mm}$ compr., glabro; corola não observada. Fruto 5,8-7 cm compr., cálice persistente; estipe 0,7-1,5 cm compr.; núcleo seminífero 1,4-2× $1 \mathrm{~cm}, 3 \mathrm{~mm}$ diâm., castanho-claro a escuro, glabro, superfície lisa, fibroso; asa 3-4×1$1,2 \mathrm{~cm}$, falcada, apresentando ângulo menor que $90^{\circ}$ em em relação ao núcleo seminífero, homogênea, glabra, lisa, reticulada, cartácea, ápice obtuso, mucronulado, margem encurvadada.

Material examinado: BOLÍVIA. CHUQUISACA: 1.XII.1910, est., T. Herzog 1169(L); SANTACRUZ, Velasco: 21.III.1994, fr., R. Guillén et al. 1088 (NY). BRASIL. AMAZONAS: Rio Guaporé, 8.VI.1952, fr., G. A. Black \& E. Cordeiro 52-14758 (IAN).

Fenologia: floração não conhecida e frutificação de março a junho.

Hábitat e distribuição geográfica: Províncias Yungas e Chaquenã, 350 a 900 m.s.m., em região pedregosa, solo argiloso arenoso. BOLÍVIA e BRASIL: AMAZONAS.
Rudd (1972) observou uma afinidade dessa espécie com $M$. nyctitans e $M$. scleroxylon. De fato, a espécie assemelha-se principalmente a $M$. scleroxylon da qual distingue-se pelos folíolos membranáceos, em menor número e pelos frutos com núcleo seminífero liso, da cor da asa. As características da inflorescência e das flores foram baseadas na descrição original da espécie apresentada pela autora e não foi completada devido ao pouco material fértil desta espécie.

11. Machaerium scleroxylon Tul., Arch. Mus. Hist. Nat. 4: 93. 1844., "scleroxylum". Typus: BRASIL. MINAS GERAIS: 1838, fr., P. Claussen 98, Cat. herb. Bras. Mus. Par. n. 884. (Holótipo P; Isótipo S!). Fig. 11

Machaerium nyctitans var. scleroxylon (Tul.) Hassler, In: Fedde, Rep. Sp. 12:371. 1913. Árvore 6 a $30 \mathrm{~m}$ alt. Tronco reto, $24-70 \mathrm{~cm}$ diâm., acúleos até $3 \mathrm{~cm}$ compr. nos rebrotos, lineares a triangulares, casca variegada na planta jovem, esfoliante na adulta, despregando placas longitudinais. Ramos 2-8 mm diâm., sulcados, acinzentados, castanhos a enegrecidos, glabrescentes, lenticelados, espinescentes ou não, quando novos 1-3 mm diâm. Estípulas (1-) $2-7(-18) \mathrm{mm}$ compr., lineares a triangulares, retas, espinescentes, persistentes, às vezes decíduas. Folhas 4-8,5(-11,5) × 2-7 cm, 919-folioladas; pecíolo 0,5-1,5 cm compr., 0,5$1 \mathrm{~mm}$ diâm., cilíndrico, hialino a ferrugíneopuberulento a tomentoso; raque $3-7 \mathrm{~cm}$ compr., 0,5-1 mm diâm., cilíndrica a canaliculada, indumento como no pecíolo; peciólulo 1-2 mm compr. Folíolos alternos, $1-2,7(-4,6) \times 0,5-1,2$ $(-1,5) \mathrm{cm}$, ápice obtuso, retuso, base arredondada, obtusa, cuneada a oblíqua, cartáceos, levemente discolores, margens inteiras, espessadas, ligeiramente revolutas, superfície adaxial esparsamente hialino-puberulenta a serícea, principalmente na nervura central, glabrescente, superfície abaxial hialino a ferrugíneo-puberulenta a serícea, às vezes vilosa na base, venação broquidódroma. Racemos ou panículas, 1,5-5,5 × 1-4,5 cm, 


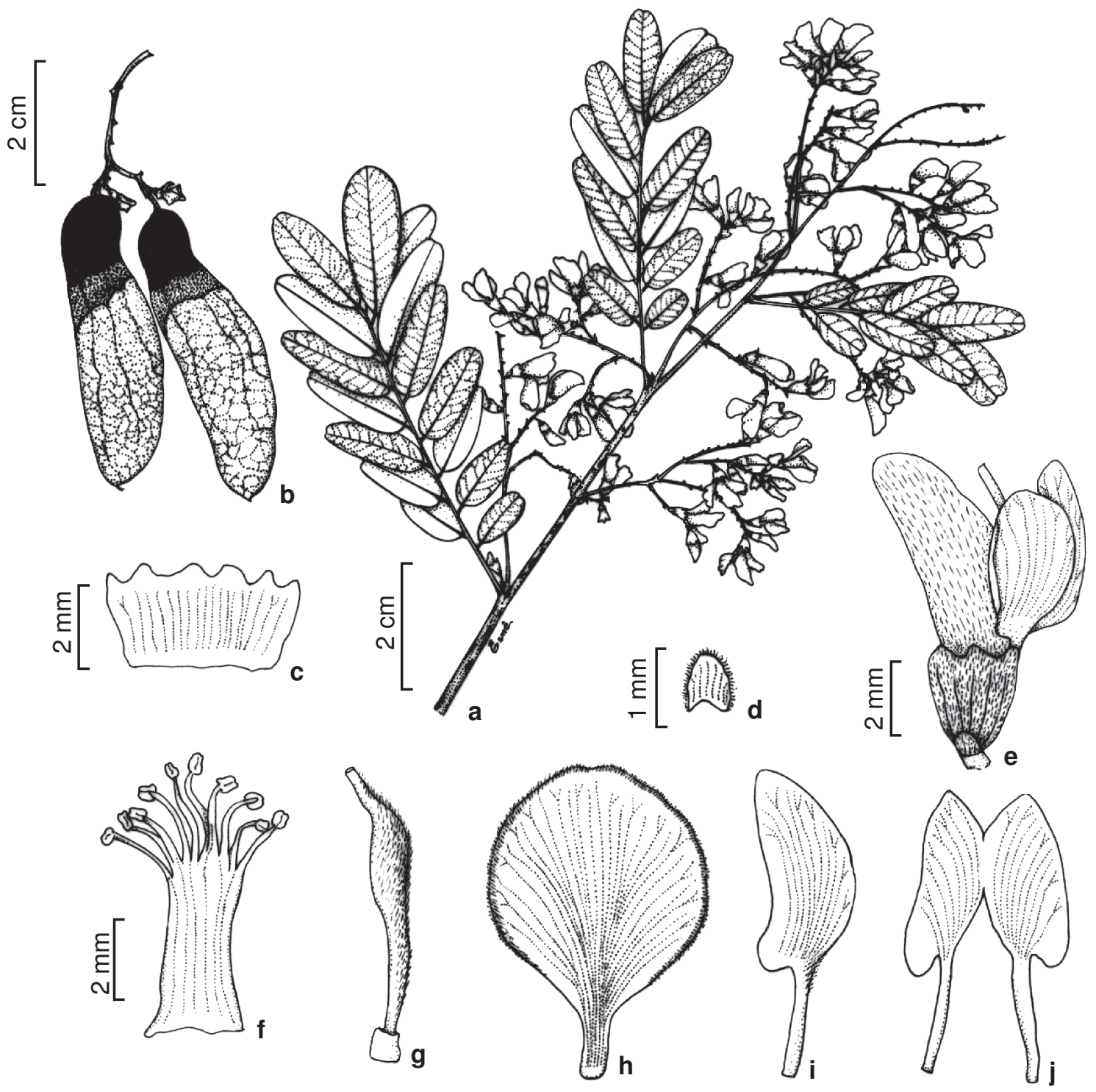

Figura 11 - Machaerium scleroxylon Tul. - a. ramo e inflorescência; b. fruto; c. cálice; d. bractéola; e. flor em antese; f. androceu; g. gineceu; h. vexilo; j. asa; 1. pétalas da carena. (a Alvarenga 2518; b Heringer 3693; c-1 Hatschbach 61460)

até 0,5 do comprimento das folhas, axilares, às vezes terminais, laxas ou congestas no ápice; pedúnculo (0-)0,5-1 cm compr., 1 mm diâm.; raque (0-)0,3-5 cm compr., hialino a ferrugíneotomentosa; eixos laterais $0,5-1,5(-3) \mathrm{cm}$ compr., indumento como na raque. Brácteas $(0,8-) 1-3 \times 0,5-1,5 \mathrm{~mm}$, triangulares a orbiculares, hialino a ferrugíneo-tomentosas a seríceas. Flores sésseis, 5-10 mm compr., bractéolas $1 \times 1 \mathrm{~mm}$, orbiculares, lisas, ferrugíneo-puberulentas a tomentosas; cálice
1,2-4×1,2-3 mm, 1,7-2 mm diâm., superfície estriada longitudinalmente, ferrugíneopuberulenta a serícea, lacínios lobados, obtusos, os carenais $0,4-0,5 \times 0,5 \mathrm{~mm}$, os vexilares $0,4-0,5 \times 0,8 \mathrm{~mm}$; corola $2,5-3,5$ vezes o comprimento do cálice, pétalas creme, amareladas a róseo-esbranquiçadas, com nervuras avermelhadas, dicotômicas, às vezes inconspícuas, como também as superfícies internas das bractéolas e do cálice; vexilo 5,58,4 × 4-7,7 mm, largo-obovado, superfície 
externa ferrugíneo-serícea, superfície interna ferrugíneo-tomentosa na margem, ápice retuso, base atenuada, unha 1-2 mm compr.; asas 4,38×2-3 mm, elípticas, ferrugíneo-seríceas no dorso, às vezes esparsamente ferrugíneoseríceas no ápice, membranáceas, ápice obtuso, base oblíqua, auriculadas ventralmente, às vezes com dobras, unha 1,5-2,8 mm compr.; pétalas da carena $3,2-8 \times 2 \mathrm{~mm}$, elípticas, ferrugíneo-seríceas a glabras no dorso, membranáceas, ápice agudo, base oblíqua, auriculada ventralmente, unha 1,5-3 mm compr.; estames 10, monadelfos, soldados até 2,5-3,5 mm compr.; filetes 2,5-6 mm compr., esparsamente ferrugíneo-seríceos no dorso a glabros; anteras $0,5-0,8 \times 0,3-0,5 \mathrm{~mm}$, oblongas; disco nectarífero $0,6-1,5 \times 0,5-1 \mathrm{~mm}$, cupulado; ovário estipitado, 2-3 × $1 \mathrm{~mm}$, ferrugíneotomentoso a seríceo; estipe 1-2,5 mm compr., ferrugíneo-seríceo; estilete 1-1,5 mm compr., glabro, às vezes esparsamente ferrugíneoseríceo. Fruto 3-6,5 cm compr.; estipe 0,5$0,8 \mathrm{~cm}$ compr., ferrugíneo-seríceo; núcleo seminífero 1-2 ×0,6-1 cm, 2-4 mm diâm., castanho-escuro a enegrecido, hialino a ferrugíneo-puberulento a seríceo, superfície estriada, 2-4 nervuras longitudinais prolongadas em direção a asa, fibroso; asa 2,3-3,6 × 1$1,6 \mathrm{~cm}$, oblanceolada, às vezes falcada, formando com o núcleo seminífero ângulo maior que $90^{\circ}$, pardacenta, discolor, castanhoclara na base, esparsamente hialinopuberulenta, glabrescente, reticulada, cartácea, ápice agudo a obtuso, margem plana ou levemente encurvada; semente $1-1,2 \times 0,6 \mathrm{~cm}$, reniforme; testa $1 \mathrm{~mm}$ de espessura, castanhoclara, ruminada desde a rafe até a metade da semente, o restante corrugada, membranácea; embrião com promórdios foliares pluripinulados. Material examinado: BOLÍVIA. Florida: $6 \mathrm{~km}$ al $\mathrm{N}$ de Bermejo, tramo de 2-3 km al NW de la escuela en la comunidad, 4.IX.1996, fr., I. G. Vargas 5095 (NY); SANTACRUZ: Velasco, San Juancito, $27 \mathrm{~km}$ al N de San Ignácio, 1.V.1986, fr., R. Seidel \& S. G. Beck 357 (NY); PARAGUAI. Cerro Margarita, 1901.1902, fr., E. Hassler 11053 (AMES, BM, NY, S, UC); BRASIL. BAHIA: Itambé, 1.III..1993, fr., M. C. Guedes et al. 2875 (ALCB); Santana, próximo ao Riacho da
Gameleira, 19.V.1984, fr., M. M. Santos 80 (HRB); GOIÁS: Amarelina, Rio Formiga, 22.VIII.1996, fr., S. S. Silva et al. 21 (NY); Cabeceiras, km 29 rod. que parte de Unaí, 22.XI.1996, fl., B. A. S. Pereira \& D. Alvarenga 3260 (IBGE); MINAS GERAIS: Corumbataí, estrada para Rio Claro-SP, 30.VII.1992, fr., H. Lorenzi 28788 (UEC); Januária, estrada de terra para Riacho da Cruz, 18.IX.1994, fr., G. F. Árbocz 663 (UEC); Virgem da Lapa, I.1998, fl., E. Tameirão 2531 (BHCB); PARANÁ: Cerro Azul, 5.VIII.1966, fr., J. C. Lindeman \& J. H. Hass 2027 (U); Dr. Ulysses, Cabeceiras do Ribeirão do Tigre, 7.XI.1994, fl., G. Hatschbach \& J. M. Silva 6140 (BHCB, C, CEPEC, MBM, NY, SPF, UB); SÃO PAULO: Agudos, Faz. Sta. Rita, 25.XI.1997, fl., $P$. F. A. Camargo \& S.R. Christianini 506 (BAUR, UEC); Amparo, Monte Alegre, 5.IV.1943, fr., $M$. Kuhlmann 572 (SP).

Fenologia: floração de setembro a abril e frutificação de outubro a agosto.

Hábitat e distribuição geográfica: floresta mesófila, floresta costeira, mata seca, cerradão, em regiões calcáreas, em áreas periodicamente inundáveis, com solo argiloso ou arenoso. Bolívia e Paraguai. Brasil: Bahia, Goiás, Minas Gerais, Paraná e São Paulo.

Nome popular: "candeia-do-sertão", "candeia", "caviúna”, "caviúna-rajada”, “caviúna-vermelha”, "gaviúna”, "jacarandá-caviúna”, jacarandávioleta", "pau-ferro", "penanguba", "uruvaeiro", "violeta" (Brasil); "canela-do-brejo", "espuela-degallo”, "guayacán-morotî", “sapy’y” (Paraguai).

As principais características que diferenciam essa espécie de outras afins, como M. floridum, M. hatschbachii, M. ruddianum e $M$. nyctitans, são as flores odoríferas, o tronco variegado quando jovem, com casca esfoliante, desprendendo placas longitudinais quando adulto, as bractéolas orbiculares, o cálice estriado longitudinalmente, com lacínios obtusos no ápice, os frutos com núcleo seminífero enegrecido e asa discolor na base. Diferencia-se de $M$. nyctitans pelos acúleos menores, menor número de folíolos, revestimento menos denso, inflorescência pauciflora, laxa, características também observadas por Sartori e Tozzi (1998), e frutos com asa pardacenta, discolor na base. M. scleroxylon apresenta ainda folíolos maiores e menos numerosos que os de $M$. hatschbachii. 
Hoehne (1941) comentou que houve um equívoco de Tulasne ao descrever M. scleroxylon como inerme e ressaltou a utilização da madeira desta espécie para construções. Um estudo do potencial de utilização da madeira foi apontado por Bernadi (1984), por ela ser pesada, dura e de cor forte. A madeira entretanto é apontada como causadora de alergia ao contato (Pickel 1962).

12. Machaerium tortipes Hoehne, Arq. Bot. Estado São Paulo 1(2): 49. 1939. Typus: BRASIL. ACRE: Rio Branco, em capoeirão de terra firme, 2.IV.1933. fl. e fr., A. Ducke s.n. (Holótipo RB!; Isótipos K!, S!, SP, SPF!).

Fig. 12

Arbusto a árvore 6-10(-30) $\mathrm{m}$ alt. Tronco 25-60 cm diâm., inerme, casca escamosa, estriada, esfoliante. Ramos 3-5,5 mm diâm., lisos, fulvo-tomentosos a glabros, lenticelados, inermes, quando novos fulvo-seríceos, com esparsos tricomas de base dilatada. Estípulas $4,5-5 \times 1,2-1,5 \mathrm{~mm}$, triangulares, retas, espinescentes, decíduas. Folhas (13-)18-26,5 $\times 3,5-6,5 \mathrm{~cm}, 21-25$-folioladas; pecíolo 2-2,5 cm compr., 1,5-1,7 mm diâm., hialino-puberulento a fulvo-tomentoso, a glabro; raque $15-19 \mathrm{~cm}$ compr., 1,2-1,4 mm diâm., indumento como no pecíolo; peciólulo 1-3 $\mathrm{mm}$ compr. Folíolos alternos, 3-5,6×(0,8-)1,5-1,8 cm, ápice obtuso, mucronulado, base arredondada a cuneada, cartáceos, discolores, margens revolutas, espessadas, superfície adaxial esparsamente hialino-serícea a glabra, superfície abaxial fulvo-serícea, venação broquidódroma. Racemos ou panículas, 3,6-7,2(-17) × 1,2-4,8 $(-15) \mathrm{cm}, 2$ a 5 vezes o comprimento das folhas, axilar ou terminal, flores congestas; pedúnculo 0,5-1,7 cm compr., $1,5 \mathrm{~mm}$ diâm.; raque $0-7 \mathrm{~cm}$ compr., fulvo-tomentosa, com esparsos tricomas de base dilatada; eixos laterais 1,3$3 \mathrm{~cm}$ compr., indumento como na raque. Brácteas $1-3 \times 0,5-2 \mathrm{~mm}$, triangulares a ovadas, fulvoseríceas a glabras, papiráceas a cartáceas, estriadas, decíduas. Flores sésseis, $10 \mathrm{~mm}$ compr.; bractéolas 4,2-4,4 $\times 0,5 \mathrm{~mm}$, linearlanceoladas, lisas, fulvo-seríceas, carnosas; cálice $5 \times 2 \mathrm{~mm}, 2 \mathrm{~mm}$ diâm., campanulado, superfície lisa, fulvo-serícea, carnoso, lacínios triangulares, os carenais $1 \times 0,5 \mathrm{~mm}$, os vexilares $1 \times 1,3 \mathrm{~mm}$; corola 2,5 vezes o tamanho do cálice, alvo-rosada, estrias lilases; vexilo $10 \times 5,5 \mathrm{~mm}$, orbicular, superfície externa fulvo-serícea, superfície interna glabra, carnoso, ápice mucronulado, base atenuada, unha 2,6 mm compr.; asas $12 \times 2,2 \mathrm{~mm}$, oblongas, fulvo-puberulenta no ápice, membranáceas, ápice obtuso, base auriculada, unha 3,5 mm compr.; pétalas da carena 11 $\times 2,5 \mathrm{~mm}$, elípticas, conatas, glabras, membranáceas, ápice agudo, base auriculada, unha $3 \mathrm{~mm}$ compr.; estames 10, diadelfos; filetes 4,2-6 $\mathrm{mm}$ compr., esparsamente fulvo-puberulentos na margem da bainha; anteras $0,2 \times 0,2 \mathrm{~mm}$, oblongas; disco nectarífero, inconspícuo, cupulado; ovário estipitado, $3,2 \times 1,4 \mathrm{~mm}$, fulvo-seríceo, uniovulado; estipe $3,7 \mathrm{~mm}$, fulvo-seríceo; estilete $1,5 \mathrm{~mm}$ compr., glabro; estigma capitado. Fruto 7-7,5 cm compr.; estipe $0,5 \mathrm{~cm}$ compr., fulvo-seríceo; núcleo seminífero $1,3-1,6 \times 1-1,2 \mathrm{~cm}, 2-3 \mathrm{~mm}$ diâm., castanho-claro, fulvo-puberulento, superfície lisa, reticulada, fibroso; asa 4,5-5,3 $\times 1,3-1,5 \mathrm{~cm}$, oblonga, apresentando ângulo menor que $90^{\circ}$ em relação ao núcleo seminífero, homogênea, glabra, lisa, reticulada, cartácea, ápice obtuso, às vezes mucronulado, margem plana.

Material examinado: BOLÍVIA. LAPAZ: Yungas, Rio Bopi, VII.1939, fr., B. A. Krukoff 10274 (K, AMES, MO, LP, UC, S, NY); PERU. HUÁNUCO: Puerto Inca, 16.I.1991, fl., Tello 1139 (NY); JUNIN: próximo a San Ramon, VI.1988, fr., E. Meneses \& $R$. Pisculich 28 (K); BRASIL. ACRE: Cruzeiro do Sul, 11.III.1992, fl. e fr., C. A. C. Ferreira et al. 10761 (NY); idem, Guiomar Santos, 27.II.1980, fl., H. C. Lima 1212 (RB); idem, Seringal Boa Água, 25.VII.1972, est., N. T. Silva 22-215(US).

Fenologia: floração janeiro a março e frutificação março a julho.

Hábitat e distribuição geográfica: floresta mesófila e cerrado, em áreas montanhosas. Bolívia (220 a 900 m) e Peru. Brasil: Acre.

Essa espécie difere de $M$. nyctitans pelo maior tamanho das folhas e do folíolo 


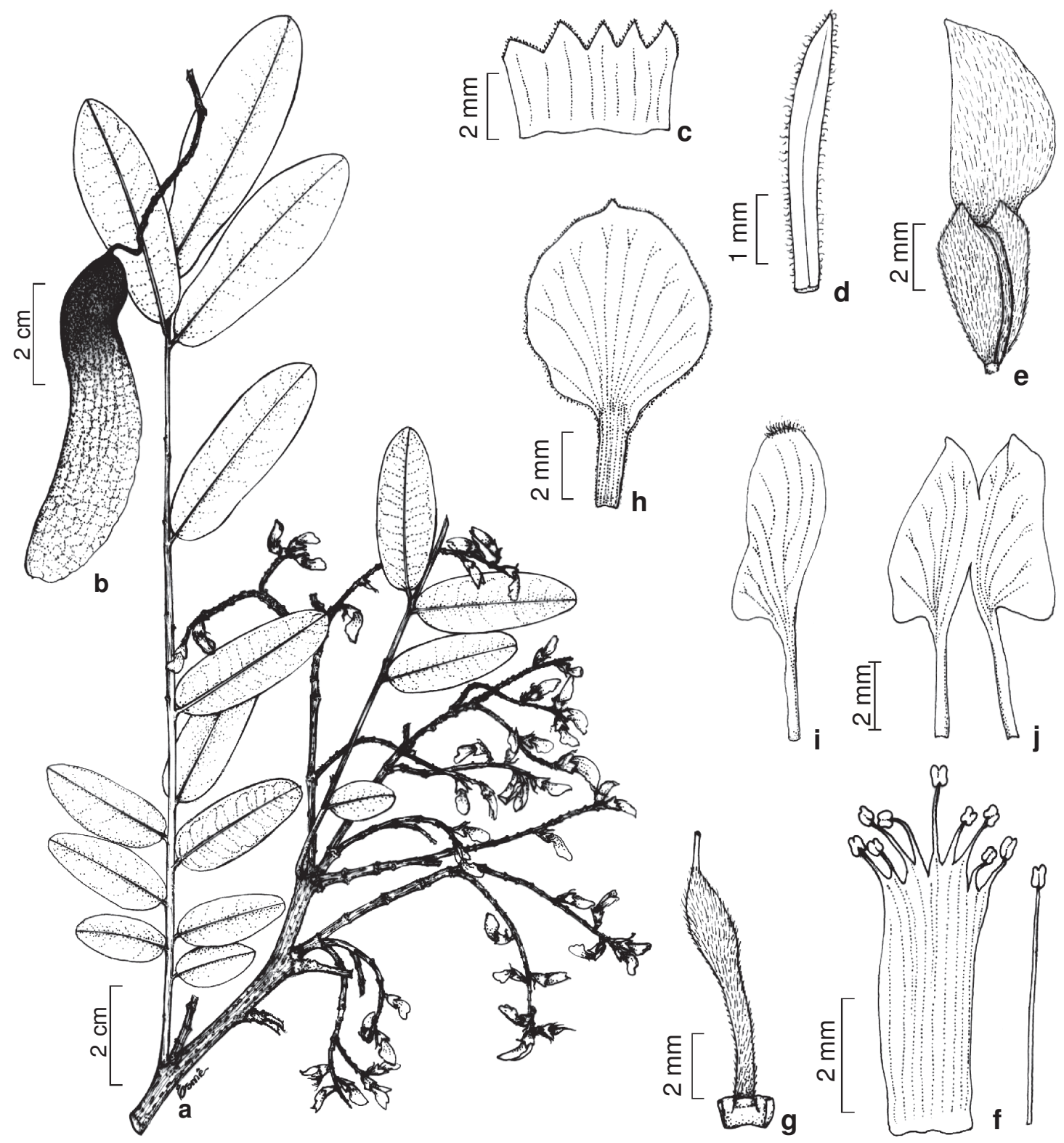

Figura 12 - Machaerium tortipes Hoehne - a. ramo e inflorescência; b. fruto; c. cálice; d. bractéola; e. flor em antese; f. androceu; g. gineceu; h. vexilo; j. asa; 1. pétalas da carena. (a Ducke s.n. (RB 24198); b-1 Lima 1212)

terminal, pela inflorescência menos ramificada e pelo vexilo com unha mais longa. Difere-se dessa espécie e também de $M$. ovalifolium pelas asas, pétalas da carena e ovário maiores, androceu diadelfo e núcleo seminífero mais largo. Dessa última difere-se também pelo estipe mais longo e estilete mais curto.

Os caracteres diagnósticos para a identificação das espécies de Machaerium sect. Oblonga, foram o tamanho dos folíolos, partes florais e dos frutos; as formas das bractéolas, dos lacínios do cálice e do vexilo e particularmente, no gineceu, o tamanho do disco nectarífero, estipe e do estilete. A ocorrência de um androceu monadelfo, raras vezes diadelfo (o vexilar livre), é um caráter unificador da seção, além da presença de folíolos oblongos, destacada nos primeiros estudos com a seção e possivelmente, a ocorrência de uma plúmula pluripartida no embrião. 
As espécies apresentaram um padrão de distribuição principalmente restrito à Região Sudeste do Brasil e a estados vizinhos, mas foram também observadas espécies com distribuição muito restrita, como no caso de $M$. obovatum e com distribuição ampla como $M$. nyctitans, $M$. scleroxylon e M. myrianthum. Essa última espécie bem como M. tortipes, M. goudoti e M. saraense representaram uma disjunção da seção, ocorrendo na região amazônica.

\section{Conclusões}

Machaerium sect. Oblonga com 12 espécies, é a terceira maior seção de Machaerium ficando atrás de $M$. sect. Reticulata e M. sect. Lineata, com cerca de 31 e 29 táxons, respectivamente. O estudo permitiu estabelecer os limites taxonômicos entre espécies de difícil delimitação como M. nyctitans, M. ovalifolium, M. scleroxylon, M. floridum e $M$. ruddianum. A determinação de novos sinônimos como $M$. kuhlmannii, sinônimo de M. nyctitans, auxiliou no entendimento deste complexo taxonômico. Foi possível também atualizar as informações taxonômicas das demais espécies da seção, bem como as informações sobre distribuição geográfica, hábitat e fenologia, ampliando o atual conhecimento sobre as espécies de Machaerium. Para completar o estudo com o gênero é necessário ampliar o número de coletas, principalmente nas Regiões Norte e Nordeste, bem como realizar revisões taxonômicas das demais seções de Machaerium.

\section{Agradecimentos}

Agradecemos à Fundação de Amparo à Pesquisa do Estado de São Paulo (FAPESP) pela concessão da bolsa de doutorado (98/ 02889-3) e da reserva técnica (98/6378-3) para o primeiro autor, sem os quais não seria possível a execução deste trabalho; aos curadores dos herbários nacionais e internacionais pelo empréstimo do material examinado, à Esmeralda Zanchetta Borghi pelas ilustrações e aos revisores pelas críticas e sugestões.

\section{REFERÊNCIAS BIBLIOGRÁFICAS}

Andrade-Lima, D. 1996. Atlas Geográfico do Brasil. IBGE, Rio de Janeiro.

Barroso, G. M. 1965. Leguminosas da Guanabara. Archivos do Jardim Botânico do Rio de Janeiro 18: 109-177.

Bastos, M. N. C. 1987. Contribuição ao estudo de algumas espécies do gênero Machaerium Persoon (LeguminosaePapilionoideae), ocorrentes na Amazônia brasileira. Boletim do Museu Paraense de História Natural 3(2): 183-278.

Bentham, G. 1860. Synopsis of Dalbergieae a tribe of Leguminosae. Journal of the Linnean Society, Botany 4: 1-128. 1862. Machaerium. In: Martius, C. F. P. von \& Eichler, A. W. (eds.). Flora brasiliensis. Munchen, Wien, Leipzig 15 (1): 232-259.

Bernadi, L. Contribuição a la dendrologia Paraguaya. 1. 1984. Boissiera 35: 307-320.

Cabrera, A. L. \& Willink, A. 1973. Biogeografia de America Latina. Secretaria Geral da Organização dos Estados Americanos, Washington, DC, $126 \mathrm{p}$.

Carvalho, A. M. V. 1997. A synopsis of the genus Dalbergia (Fabaceae: Dalbergieae) in Brazil. Brittonia 49(1): 87-109.

De Candolle, A. P. 1825. Podromus Systematis Naturalis Regni Vegetabilis 2: 258.

Ducke, A. 1922. Plantes nouvelles ou peu connues de la region amazonienne II. Arquivo do Jardim Botânico do Rio de Janeiro 3: 146-152.

1949. As leguminosas da Amazônia brasileira. Boletim Técnico do Instituto Agronômico do Norte 18: 4-248.

Guerra, M. S. 1988. Introdução a citogenética geral. Guanabara, Rio de Janeiro, 142p.

Hoehne, F. C. 1941. Leguminosas Papilionadas (Machaerium e Paramachaerium). Flora brasilica 25(3): 1-99.

Holmgren, P. K., Holmgren, N. H. \& Barnett, L. C. 1990. Index herbariorum. Part I: The 
herbaria of the world. 8th ed. New York Botanical Garden, New York, 693 pp.

Lewis, G. P. 1987. Legumes of Bahia. Royal Botanic Gardens, Kew, 369p.

Lima, H. C.; Correia, C. M. B. \& Farias, D. S. 1994. Leguminosae In: Lima, M. P. M. \& Guedes-Bruni, R. R. (orgs.). Reserva Ecológica de Macaé de Cima, Nova Friburgo-RJ: Aspectos florísticos das espécies vasculares 1: 167-228.

Lima, H. C. 1995. Leguminosas da Flora Fluminensis-J.M. da C. Vellozo- Lista atualizada das espécies arbóreas. Acta Botanica Brasilica 9(1): 123-146.

Mendonça-Filho, C. V. 1996. Braúna, Angico, Jacarandá e outras Leguminosas de Mata Atlântica: Estação Biológica de Caratinga, Minas Gerais. Fundação Botânica Margaret Mee, Belo Horizonte, 100p.

; Forni-Martins, E. R. \& Tozzi, A. M. G. A. 2002. New chromosome counts in Neotropical Machaerium Pers. species (Fabaceae) and their taxonomic significance. Caryologia 55(2): 111-114.

Pickel, B. J. A. 1962. Caviúna legítima do Brasil. Arquivos de Botânica do Estado de São Paulo. 3: 237-239.
Radford, A. E.; Dickison, W. C.; Massey, J. R. \& Bell, C. R. 1974. Vascular Plant Systematics. Harper \& Row, New York, 891p.

Rudd, V.E. 1972. New taxa and combinations in Machaerium (Leguminosae) II. Phytologia 24(2): 121-125.

1973. New taxa and combinations in Machaerium (Leguminosae) IV. Phytologia 26(2): 398-403.

1977. The genus Machaerium (Leguminosae) in Mexico. Boletin de la Sociedad Botanica de México 37: 119-146.

1987. Studies in Machaerium (Leguminosae). V. History and Fossil Names. Phytologia 62(4): 277-302.

Sartori, A. L. B. \& Tozzi, A. M. G. A. 1998. As espécies de Machaerium Pers. (Leguminosae Papilionoideae) ocorrentes no estado de São Paulo. Revista Brasileira de Botânica 21(3): 211-246.

Stearn, W. T. 1983. Botanical Latin. 3rd ed. David \& Charles Publ., Inglaterra, 566p.

Taubert, P. 1891. Machaerium. In: Engler, H. G. A \& Plant., K. A. E. (eds.). Die Naturlichen Pflanzenfamilien. 2. Aufl. Leipzig (Wilhem Engelmann). 3: 337. 